IBAD Sosyal Bilimler Dergisi

IBAD Journal of Social Sciences

dergipark.org.tr/ibad

IBAD, 2021; (11): 315-342

DOI: $10.21733 /$ ibad.910937

Özgün Araştırma / Original Article

\title{
Ergenlerde İletişim Becerileri ve Problem Çözme Becerilerinin İncelenmesi
}

Investigation of Adolescent Communication Skills and Problem Solving Skills

\author{
Nihan Uzak ${ }^{1^{*}}$ \\ Gülen Baran ${ }^{2}$ \\ * Sorumlu yazar
Corresponding author
}

${ }^{1}$ Öğretim Görevlisi, Bolu Abant İzzet Baysal Üniversitesi, Türkiye

Lec., Bolu Abant İzzet Baysal University, Turkey

nihanuzak@hotmail.com

ORCID ID 0000-0001-6803-1813

${ }^{2}$ Prof. Dr., Ankara Üniversitesi, Türkiye

Prof. Dr., Ankara University, Turkey

barangln@gmail.com,

ORCID ID 0000-0002-5854-4846

Makale geliş tarihi / First received : 07.04.2021

Makale kabul tarihi / Accepted : 23.06 .2021

\section{Bilgilendirme / Acknowledgement:}

1- Makalede isim sıralaması katkı oranına göre yazılmıştır.

2- Makalenin verileri 2020 yılı Mart ayında toplanıp yorumlanmıştır. Bolu Abant İzzet Baysal Üniversitesi, Sosyal Bilimlerde İnsan Araştırmaları Etik Kurul'u tarafından 12.11.2019 tarihinde etik olarak uygun bulunmuştur. Protokol No: 2019/343.

3- Makalenin yazarları arasında çıkar çatışması bulunmamaktadır.

4- Bu makalede araştırma ve yayın etiğine uyulmuştur.

This article was checked by iThenticate. Similarity Index 13\%

\section{Atıf bilgisi / Citation:}

Uzak, N., Baran, G. (2021). Ergenlerde iletişim becerileri ve problem çözme becerilerinin incelenmesi. IBAD Sosyal Bilimler Dergisi, (11), 315-342. 
Bu çalışmada, ergenlikte iletişim becerileri ile problem çözme becerilerine, cinsiyet, sınıf düzeyi, kardeş sayısı, doğum sırası, anne/baba öğrenim düzeyi, ve okul öncesi eğitim almanın etkisinin incelenmesi ve iletişim becerileri ile problem çözme becerileri arasındaki ilişkinin belirlenmesi amaçlanmıştır. Çalışmada, nicel araştırma yöntemlerinden nedensel karşılaştırrmalı yöntem kullanılmıştır. Araştırmanın çalışma grubunu, 2019- 2020 yılında Bolu il merkezinde resmi ortaokulların 7. ve 8. siniflarına devam eden ergenler $(n=$ 323) oluşturmuştur. Çalışmada veri toplama aracı olarak, "İletişim Becerileri Envanteri" ve "Illköğretim Öğrencileri İçin Problem Çözme Becerilerine Yönelik Algı Ölçeği" kullanılmıştır. Ayrıca Kişisel Bilgi Formu vasıtasılyla toplanan bilgiler ile ölçme araçlarından elde elden puanlar SPSS programiyla analiz edilmiştir. Veriler analiz edilirken, bağımsız örneklemler için t-testi ve tek yönlü ANOVA kullanılmıştır. Analiz sonucunda ergenlerin iletişim becerileri ve problem çözme becerileri puanlarında öğrenim gördükleri sınıf düzeyine, kardeş sayısına, doğum sırasına, anne-baba öğrenim düzeyine, okul öncesi eğitim alma durumuna ve süresine göre anlamlı bir farklılık tespit edilirken, cinsiyete göre olan anlamlı farklılığın uygulanan ölçeklerin bazı alt boyutlarında olduğu görülmüştür. Ergenlerin problem çözme becerileri ile iletişim becerileri arasındaki ilişki korelasyon analizi ile değerlendirilmiş ve aralarındaki ilişkinin anlamlı olduğu sonucuna ulaşılmıştır. 2018 y1lında toplanan Dünya Ekonomik Forumunda 2022 de iş dünyasının arayacağı ilk 10 becerinin 6 . Sırasında "kompleks problemleri çözme becerisi" ve 9. Sırasında ise "muhakeme, problem çözme ve hızlı kavrama becerisi" gibi direkt problem çözme becerisiyle ilgili beceriler yer alırken, girişkenlik, duygusal zeka, sosyal nüfus gibi iletişim becerileri ile ilgili beceriler de yine ilk 10 maddenin içinde bulunmaktadır. Erken yillarda bireylerin iletişim ve problem çözme becerilerinin kazanılmasına yönelik temellerin atıldığı düşünüldüğünde yetişkinlik yıllarına temel oluşturacak bu becerilerin kazanilmasinda sunulması gereken destekler öneriler kısmında yer almıştır.

\section{Anahtar kelimeler}

Ergen, İletişim Becerisi, Problem Çözme Becerisi
In this study, it was aimed to examine the effect of communication skills and problem solving skills in adolescence, gender, grade level, number of siblings, birth order, parents' education level, and preschool education, and to determine the relationship between communication skills and problem solving skills. The study group of the study consisted of students $(n=323)$ attending 7 th and 8 th grades of official secondary schools in the city center of Bolu in 2019- 2020. In the study, "Communication Skills Inventory" and "Perception Scale for Problem Solving Skills for Primary School Students" were used as data collection tools. In addition, the information collected through the Personal Information Form and the scores obtained from the measurement tools were analyzed with the SPSS 20.0 program. While analyzing the data, descriptive statistics, independent samples t-test and one-way ANOVA were used. As a result of the analysis, a significant difference was detected in the communication skills and problem solving skills scores of adolescents according to their grade level, number of siblings, order of birth, parents' education level, pre-school education status and duration, while the significant difference according to gender It was found to be in size. The relationship between problem solving skills and communication skills of adolescents was evaluated using correlation analysis and it was concluded that the relationship between them was significant. The importance of the research is the fact that communication and problem solving skills will be much more important for recruitment in the coming years. In the World Economic Forum held in 2018, the first 10 skills that the business world will look for in 2022 are "complex problem solving skills" and the 9th is "reasoning, problem solving and quick comprehension skills", while assertiveness and emotional Skills related to communication skills such as intelligence and social population are also among the first 10 items. Considering that the foundations were laid for the acquisition of communication and problem solving skills in the early years, the support that should be offered in the acquisition of these skills that will form the basis of adulthood is included in the recommendations section.

\section{Keywords}

Adolescent, Communication Skill, Problem Solving Skill 


\section{GíRiş}

Ergenlik genel anlamda bireyin çocukluktan yetişkinliğe geçerken yaşadığı süreç olarak ifade edilebilir. Ergenliğin ilk yılları bazı kaynaklarda erinlik (Kılıç, 2013), bazı kaynaklarda erken ergenlik (Akçinar, Baydar ve Kağıtçıbaşı 2018; Steinberg, 2007) olarak ele alınır ve 10-14 yaş arası birçok değişimin başladığı dönem olarak kabul edilir. Kılıç (2007) bu dönemi anlatırken "bir ayağ1 çocuklukta, diğeri ergenlikte olan birey" ifadesini kullanmıştır. Erken ergenlik birçok değişimin aynı ayna yaşandığı bir dönemdir. Bu dönemde bireyler bazı durumlarda çocuk kabul edilirlerken, bazı durumlarda yetişkin olarak kabul edildiklerini ifade ederler ve bunu anlamlandıramadıklarından bahsederler. İnsan yaşamında birkaç yıl gibi kısa bir süreyi kapsayan erken ergenliğin "çabuk değişme" olarak ifade edildiğine de rastlamak mümkündür (Andersen, 2003; Dahl, 2004; Spear, 2000). Bu değişim neticesinde tutumda, kendini algılama biçiminde, davranışlarda ve kurulan ilişkilerde farklılaşmaların meydana gelmesi söz konusudur. Bu dönemde birey aynı anda birçok karmaşayla uğraşır, bir taraftan hayatın problemleri ile boğuşurken aynı zamanda özgüven sıkıntıları da yaşamaya başlayabilir. Bu dönemde sıklıkla iyimser düşünme biçiminin yerini kötümser düşünme biçimine bıraktığına rastlanabilir (Kılıç, 2007). Ayrıca ergenlik bireyin bağımlı olma durumundan bağımsız olma durumuna, özerkliğe ve olgunluğa geçtiği gelişim dönemidir (Akdeniz, 2017; Geldard ve Geldard, 2013). Birey bu döneme kadar sadece bir aile grubunun üyesi iken bu dönemle birlikte artık arkadaş grubunun üyesi olmaya ve tek başına ayakta kalma becerisini de kazanmaya başlamıştır (Erikson, 1982). Bu dönemde yaşanan gelişimler ve değişimler doğrusal bir düzlemde ilerlemeden çok daha fazlasını içinde barındırır. Yaşanan değişimler çok boyutlu olmakla birlikte, bu değişimler süresince gençlerden beklentiler kültürden kültüre farklılık gösterir (Geldard, 2013).

İletişimin birçok tanımı yapılmasına rağmen, belirlenmiş bir konuda, bireyler arasında istenen sonuçlara ulaşmak ve/veya davranışları değiştirebilmek amacıyla, sözlü ya da sözlü olmayan yöntemlerin kullanılmasına dayanan bir süreç olarak tanımlamak mümkündür (Kavruk ve Tan, 2001; Yorulmaz ve Kıraç, 2019). İletişim sadece sözlü olmak zorunda olmadığ gibi, neyin, ne zaman, nasıl ifade edilmesi gerektiği noktasındaki doğru kararları alma süreci olduğu da bilinmelidir. İletişim tek taraflı bir süreç değildir, bu süreçte bir taraftan kendi düşüncelerimizi karşı tarafa aktarmaya çalışırken, diğer taraftan da karşı tarafın bizi anlayıp anlamadığını kontrol etmemiz iletişimin çok önemli bir parçasını oluşturur (Yavuzer, 2009). Birçok karmaşık durumun yaşandığı ergenlik döneminde ise iletişim çocukluktan farklılaşmaya başlar. Ergenlik dönemindeki sosyal gelişimi etkileyen en önemli faktör hiç kuşkusuz ergenin yaşamını idame ettirdiği ortamdır. Bu ortam, içinde yer aldığı kültür, aile, okul ortamı ve arkadaş gruplarıdır (Akkaya, 2018; Aydın, 2005).

Problem ise "bir kişinin içinde yer aldığı durumdan başka bir duruma geçerken karşılaştığ1 engeller" olarak tanımlanabilir (Cüceloğlu, 1997). Yapılmış birçok tanım incelendiğinde kişinin bir amaca ulaşma isteği ve bu süreçte yaşadığı zorluklar gibi bazı ortak noktaları olduğu fark edilmektedir (Akman, 2007). Problem çözme sürecini etkileyen çok fazla etken bulunmaktadır. Bu etkenler içinde kişilik özellikleri önemli bir yer tutmaktadır. Bireyin kişilik özelliklerinden iletişim becerileri de bu anlamda önem taşımaktadır. Problem çözme becerisinin iletişim ile ilgisini araştıran çalışmalarda problem çözme becerisi zayıf olan bireylerin iletişim becerilerinin de zayıf olduğu vurgulanmaktadır (Akkaya, 2018; Gülay Ogelman ve Sarıkaya, 2013). Ergenlik dönemine özgü durumlardan bir diğeri de ergenin daha fazla yalnız başına kalma isteği 
duymasıdır. Ancak bu durum sürekli yalnız zaman geçireceği ve ailesi ile hiçbir ilişki içine girmeyeceği gibi bir anlam taşımamalıdır. Kurulan iletişim ergenlerin sorunlarını zamanında anlamaya ve duruma uygun çözümler üretilmesine yardımcı olacaktır (Abalı, 2004). Her ne kadar ergen bu dönemde aileden ayrı kalma isteği duysa da, bu duruma ailenin ergen üstündeki öneminin azalacağı anlamı yüklenmemelidir (Kocayörük, 2010). Ergenlik birçok açıdan değişimlerin yaşandığ kazanımıdır ve ergenin birey olarak hayatına tek başına devam edeceği gerçeğidir. Ergen bu yıllarda, karşılaştığı pek çok problemle de tek başına baş etmek zorunda kaldığını yine bu dönemde fark eder (Erikson, 1982). Farklı yaşam koşularına uyum sağlama çabası içinde olan ergenin bu sürece uyumunu kolaylaştıran en önemli unsurlardan biri de iletişim becerileridir. İletişim becerileri gelişmiş olan ergenlerin sosyal açıdan daha az strese sahip oldukları bilinmektedir (Bayraktar, 2007; Kumru ve ark. 2004; Taylor ve ark. 2015). Gardner'a (2019) göre; uygun ortamlarda yetişen ergenler birbirlerinin görüşlerini eleştirebilmekte ve kendi yöntemlerini gözden geçirebilmektedirler. Başka bir dille ifade etmek gerekirse, kişilerarası iletişimi güçlü olan bireyler vereceği kararı tartışmaya açarak pozitif ve negatif taraflarını daha net görebilme eğiliminde olurken, kişilerarası iletişimi zayıf bireyler verdikleri kararı farklı bakış açıları ile ele alma imkânından yoksun olabilirler. Bu nedenle de seçtikleri problem çözme yaklaşımları gelişime ve değişime daha az elverişli hale gelmiş olur.

Serin ve Derin (2008) yaptıkları çalışmada, problem çözme becerisini yüksek algılayan bireylerin kişilerarası ilişkilerde daha aktif olduğu ve akademik açıdan daha başarılı olduklarını belirtmiştir. Yerli literatür incelendiğinde, ergenlerin iletişim becerileri ve problem çözme becerilerinin ayrı ayrı ele alınarak incelendiği ve yabancı literatürde iletişim becerileri ve problem çözme becerilerinin birlikte incelendiği pek çok çalışma yapılmıştır (Aksüt ve Batur, 2007; Arthur, 1975; Cenkseven ve Akar, 2006; Ekşi, 2013; Fetihi, 2002; Helen, 2017; Koçyiğit ve Özsoy 2018; Milli ve Yağc1, 2017; Monique, ve ark. 2011; Nock ve ark., 2008; Pelit, Karaçor ve Kılıç, 2018; Sadowski ve ark., 1993; Say, 2016; Sungur, 2018; Tepeköylü-Öztürk ve Soytürk, 2015; Turgut, Kutlu ve Mut, 2018; William, 2010). Çevreleriyle sağlıklı iletişim kuran bireylerin kendilerini güven içinde hissettikleri ve bu güven ortamında olayları olması gerektiği şekliyle değerlendirebildikleri bilinmektedir. İlk önce kendileriyle ve sonra da çevreleriyle olumlu ilişkiler kurabilen bireyler karşılıklı etkileşime ve beraberliğe daha açık hale gelmektedir. Problem çözümünde karşılıklı iletişim çok önemli rol oynamaktadır. İletişim problemi yaşayan bireylerin problem çözümlerinde sıkıntı yaşamaları beklenirken, yaşam doyumlarının da yüksek olma ihtimali azalmaktadır. Yani bireyin iletişim becerisini güçlendirmek ona sağlıklı etkileşim ortamı sağlamanın yanında, problem çözme yöntemlerinin de gelişimine katkı sağlayacaktır (Erözkan, 2009; Suzanne, 2020). Ülkemizde yapılmış çalışmalar incelendiğinde; ergenlik döneminde problem çözme becerileri ve iletişim becerileri ayrı ayrı ele alınmış olsa da, bu iki unsurun bir biri ile olan ilişkisini inceleyen çalışmaya rastlanmamıştır. Bu nedenle bu çalışmada ergenlerin iletişim becerileri ile problem çözme becerilerini incelemek, etki eden etmenleri ortaya koymak, ergenlerin iletişim becerileri ile problem çözme becerileri arasındaki ilişkinin değerlendirilmesi amaçlanmıştır.

\section{YÖNTEM}

Bolu Abant İzzet Baysal Üniversitesi, Sosyal Bilimlerde İnsan Araştırmaları Etik Kurul'u tarafından 12.11.2019 tarihinde etik olarak uygun bulunmuştur. Protokol No: 2019/343. 


\section{Araştırmanın Deseni}

Ergenlikte iletişim becerileri ile problem çözme becerilerine etki eden yaş, cinsiyet, doğum sırası, anne/baba öğrenim düzeyi ve okul öncesi eğitim alma gibi değişkenlere göre farklılık olup olmadığının incelenmesi ve iletişim becerileri ile problem çözme becerileri arasındaki ilişkinin belirlenmesinin amaçlandığı bu çalışma nedensel karşılaştırmalı araştırma yöntemi ile gerçekleştirilmiştir. Araştırma betimsel bir çalışmadır, iki ya da daha fazla değişken arasındaki ilişkiyi belirlemek ve neden-sonuç bağlantıları kurmak için gerçekleştirilen araştırma yöntemi olarak tanımlanmaktadır. Nedensel karşılaştırma araştırmaları var olan/ doğal olarak ortaya çıkmış bir durum ya da olayın nedenlerini ve bu nedenlere etki eden değişkenleri ya da bir etkinin sonuçlarını belirlemeye yönelik araştırmalardır (Büyüköztürk, Çakmak, Akgün, Karadeniz, Demirel, 2008).

\section{Çalışma Grubu}

Araştırmanın çalışma grubunu, Bolu il merkezinde bulunan Milli Eğitim Bakanlığına bağlı okullardan rastlantısal seçilmiş üç devlet okulu oluşturmuştur. Çalışmaya gönüllü olarak katılmayı kabul eden, \%48'i 7. ve \%51'i 8. sınıf öğrencilerinden, \%46'sı 149 kız, \%53'ü 174 erkek olmak üzere toplam 323 ergen çalışmaya dahil edilmiştir. 7. ve 8. Sınıf öğrencilerinin çalışmaya dahil edilme nedenleri bu yaş grubunun ergenliğin ilk yıllarına denk gelen 13-14 yaş grubunda olmasidir.

Tablo 1. Araştırmaya Dâhil Olan Ergenlerin Demografik Özellikleri

\begin{tabular}{|c|c|c|c|}
\hline $\begin{array}{l}\text { Demografik } \\
\text { Özellikler }\end{array}$ & Grup & $N$ & $\%$ \\
\hline \multirow[t]{3}{*}{ Cinsiyet } & Kiz & 149 & 46,1 \\
\hline & Erkek & 174 & 53,9 \\
\hline & Toplam & 323 & 100,0 \\
\hline \multirow{3}{*}{$\begin{array}{l}\text { Ögrenim Görülen } \\
\text { Sinıf Düzeyi }\end{array}$} & 7. sinif & 158 & 48,9 \\
\hline & 8. sinif & 165 & 51,1 \\
\hline & Toplam & 323 & 100,0 \\
\hline \multirow[t]{5}{*}{ Kardeş Sayı1sı } & Yok & 19 & 5,9 \\
\hline & 1 kardeş & 145 & 44,9 \\
\hline & 2 kardeş & 111 & 34,4 \\
\hline & 3 ve üzeri kardeş & 48 & 14,9 \\
\hline & Toplam & 323 & 100,0 \\
\hline \multirow[t]{5}{*}{ Doğum Sirası } & İlk Çocuk & 68 & 21,1 \\
\hline & İkinci Çocuk & 186 & 57,6 \\
\hline & Uçüncü Çocuk & 62 & 19,2 \\
\hline & Dördüncü Çocuk & 7 & 2,2 \\
\hline & Toplam & 323 & 100,0 \\
\hline \multirow{3}{*}{ Anne $\quad$ öğrenim } & İlkokul & 62 & 19,4 \\
\hline & Ortaokul & 112 & 34,6 \\
\hline & Lise & 65 & 20,1 \\
\hline
\end{tabular}




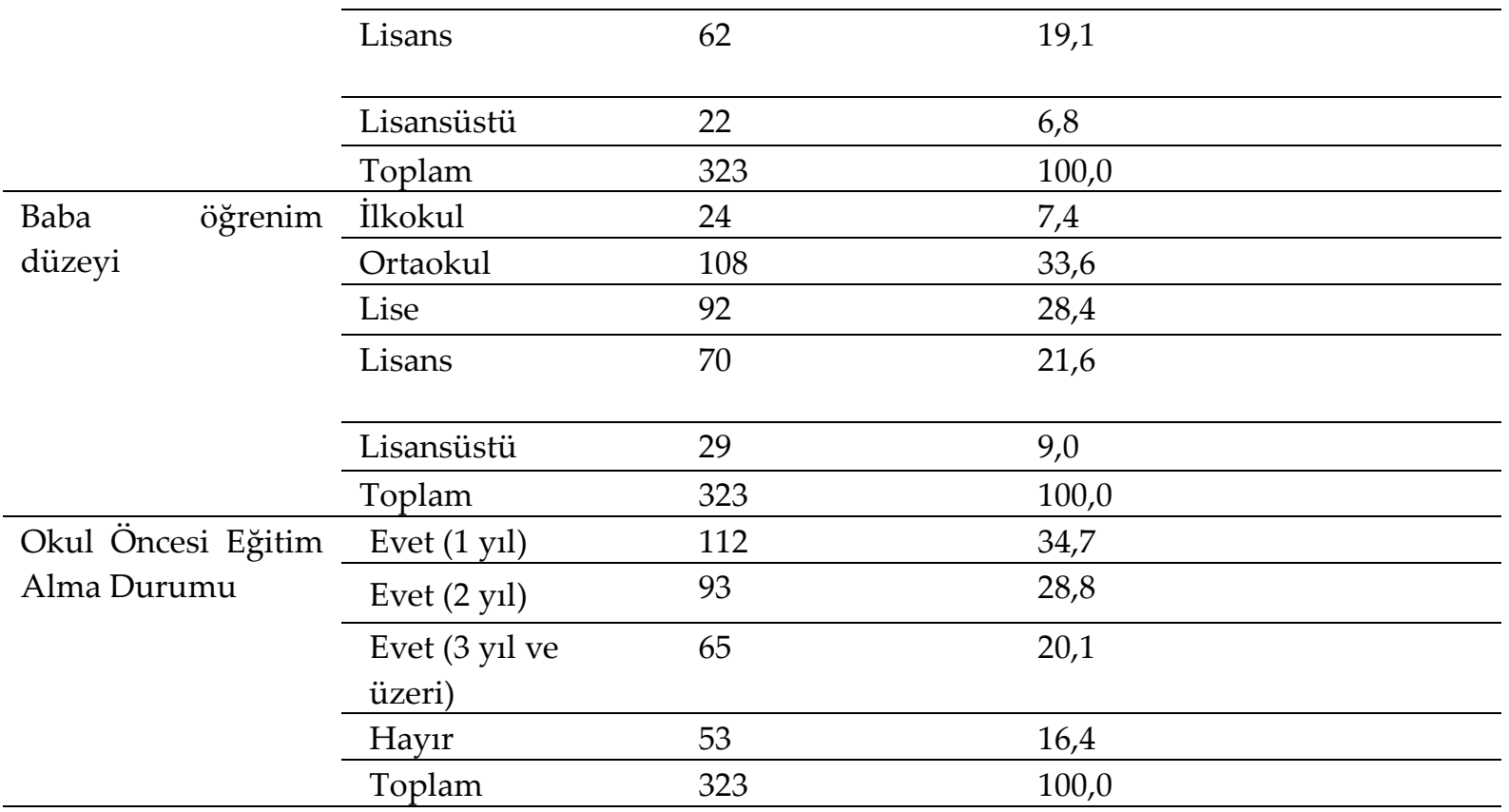

\section{Veri Toplama Araçları}

Ergenlerin iletişim becerileri ile problem çözme becerileri arasındaki ilişkinin incelenmesinin amaçlandığı bu çalışmada: çocuklara ve ailelere ilişkin demografik özellikleri belirlemek için araştırmacı tarafından hazırlanmış Kişisel Bilgi Formu, iletişim becerilerini değerlendirmek için Ersanlı ve Balcı Çelik, tarafından (1998) geliştirilmiş İetişim Becerileri Envanteri ve Ekici İnel ve Balım tarafından (2013) geliştirilmiş problem çözme becerilerini değerlendirmek için İlköğretim Öğrencileri İçin Problem Çözme Becerilerine Yönelik Algı Ölçeği kullanılmıştır.

\section{Veri Toplama Süreci}

Veri toplama aşamasından önce, araştırmanın amacını ve içeriğini açıklayan bir başvuru formu hazırlanarak Bolu Abant İzzet Baysal Üniversitesi Etik Kuruluna başvurulmuş uygulamaların yapılabileceğine dair Etik Kurul Kararı Ocak 2020'de alınmıştır. Çalışma, başlangıç aşamasında basılı materyal olarak hazırlanmıştır. Ancak uygulamanın yapılması planlanan tarihten bir hafta önce Covid-19 nedeniyle okullara ara verilmesinden dolay1 hazırlanmış bütün materyaller "Google form" üzerinden oluşturulan online form toplama aracılığı ile ergenlere ulaştırılmış ve ölçekleri doldurmaları sağlanmıştır. Çalışmaya toplam 375 ergen katılmış olmasına rağmen, çalışmanın sınırlılıklarına uymayan ergenler ile eksik veya yanlış doldurulmuş formlar değerlendirmeye alınmamıştır. Bu nedenle 323 ergen ölçek puanlarının analizlerine dâhil edilmiştir. Araştırmaya, 2019-2020 eğitim-öğretim yılında Bolu il merkezindeki resmi ortaokulların 7. ve 8. sınıflarına devam eden öğrenciler dâhil edilmiştir. Veriler, Mart 2020 - Nisan 2020 tarihleri arasında toplanmıştır.

\section{Verilerin Değerlendirilmesi ve Analizi}

Ergenlikte iletişim becerileri ile problem çözme becerilerine etki eden demografik etmenlerin incelendiği ve iletişim becerileri ile problem çözme becerileri arasındaki ilişkinin belirlenmesinin amaçlandığı bu çalışmada, "İletişim Becerileri Envanteri" ve "İlköğretim Öğrencileri İçin Problem Çözme Becerilerine Yönelik Alg1 Ölçeği” ne ilişkin puanlar hesaplanmıştır. Her ergen için iletişim becerilerine ilişkin, zihinsel, davranışsal, duygusal alt boyut ve toplam puan; problem çözme becerilerine ilişkin, problem çözme becerilerine 
yönelik algı, problem çözme becerilerine yönelik isteklilik ve kararlılık algısı ve toplam puan olmak üzere 7 ayrı puan elde edilmiştir. Kişisel Bilgi Formu vasıtasıyla toplanan bilgiler ile ölçme araçlarından elde elden puanlar SPSS 20.0 programı ile bilgisayar ortamına aktarılmıştır.

Araştırmada, kullanılacak istatistiksel analiz yöntemlerini belirlemek üzere, öncelikle bağımlı değişkene ilişkin puanların gruplardaki dağılımının normal olup olmadığı normallik testi ile incelenmiştir. Bu amaçla, basıklık ve çarpıklık katsayısı (Skewness ve Kurtosis) değerlerine bakılmıştır. Bu değerlerin -2 ile +2 arasında olması durumunda dağılımın normal kabul edilebileceğinden parametrik analiz yöntemlerinin kullanılabileceğinin altı çizilmiştir (George ve Mallery, 2010). Verilerin basıklık ve çarpıklık değerlerinin -2 / +2 aralığında olmasından dolayı dağılım normal kabul edilmiş ve parametrik yöntemler kullanılarak analizler gerçekleştirilmiştir.

Gruplar arasındaki farkı belirlemek amacıyla ikili örneklem gruplarında "T testi" kullanılırken, ikiden fazla gruba sahip olan değişkenler için Tek Yönlü Anova kullanılmıştır. Problem çözme becerisi ile iletişim becerileri arasındaki ilişkiyi incelemek için Korelasyon Analizi yapılmıştır. Ayrıca Anova ile ortaya çıkan farklılıkların hangi gruplar arasında olduğunu belirlemek amacıyla Post Hoc analizi yapılmış ve dağılım normal olduğundan dolayı Tukey testi kullanılmıştır.

\section{İletişim ve Problem Çözme Becerileri Envanterine İlişkin Normallik Testi Sonuçları}

Tablo 2. Ergenlerin İletişim Becerisinin Zihinsel, Davranışsal, Duygusal Boyutları, Problem Çözme Becerisinin Zihinsel, Davranışsal, Duygusal Boyutları ve Toplam Puana İlişkin Betimsel İstatistikleri

\begin{tabular}{lcccccccc}
\hline İletişim Becerisi & $N$ & $X$ & $\begin{array}{c}\text { S. } \\
\text { Sapm } \\
\text { a }\end{array}$ & $\begin{array}{c}\text { Varyan } \\
\text { s }\end{array}$ & Min. & Max. & Çarp. & Bas \\
\hline Zihinsel & 323 & $\begin{array}{l}45,6 \\
3\end{array}$ & 10,26 & 105,4 & 38,0 & 55,0 &,- 157 & $-1,128$ \\
& & & & & & & \\
\hline Davranışsal & 323 & 45, & 5,13 & 26,39 & 23,0 & 75,0 &, 080 & $-1,448$ \\
& 9 & & & & & & \\
\hline Duygusal & 323 & 46, & 16,2 & 264,5 & 95,0 & 197,0 &, 071 & $-1,460$ \\
& & 6 & & & & & & \\
\hline Toplam & 323 & 138 & 31,4 & 989,9 & 30,0 & 67,0 &, 109 & $-1,432$ \\
& & 2 & & & & & & \\
\hline
\end{tabular}

\section{Problem Çözme Becerisi}

\begin{tabular}{lcccccccc}
\hline $\begin{array}{l}\text { Problem Çözme } \\
\text { Becerisi }\end{array}$ & 323 & 46,1 & 16,86 & 284,3 & 21,00 & 75,00 &, 055 & $-1,498$ \\
\hline İsteklilik/ Kararlılık & 323 & 21,0 & 8,4755 & 71,83 & 9,00 & 35,00 &, 157 & $-1,548$ \\
\hline Toplam Puan & 323 & 67,1 & 25,151 & & 35,00 & 110,0 &, 125 & $-1,585$ \\
\hline
\end{tabular}


Tablo 2.' de İletişim Becerilerinin tüm boyutlarının puanları $\left(X\right.$ Zihinsel Boyut $=45.63, X_{\text {Davranıssal Boyut }}$ $\left.=45.9, X_{\text {Duygusal Boyut }}=46.6, X_{\text {Toplam Puan }}=138.2\right)$ ve Problem Çözme Becerilerinin tüm boyutlarının

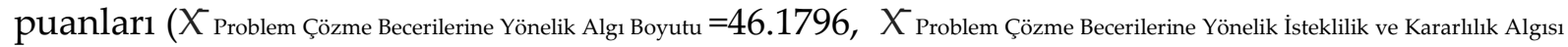
Boyutu $=21.0093, X$ Toplam Puan $=67.1889)$ belirtilmiştir. Normallik değerlendirmesi yapılırken basıklık ve çarpıklık değerleri dikkate alınmış ve verilerin normal dağıldığı kabul edilerek parametrik analiz yöntemleri kullanılmıştır.

\section{BULGULAR}

7. ve 8. sınıfa devam eden ergenlerin iletişim becerileri ile problem çözme becerilerini incelemek, etki eden etmenleri ortaya koymak, ergenlerin iletişim becerileri ile problem çözme becerileri arasındaki ilişkiyi değerlendirmek amacıyla yapılmış bu araştırmaya ilişkin bulgulara yer verilmiştir.

Tablo 3. Ergenin Cinsiyetine Göre İletişim ve Problem Çözme Becerilerine İlişkin T Testi Sonuçları

\begin{tabular}{|c|c|c|c|c|c|c|c|}
\hline İletişim Becerisi & Grup & $N$ & $X^{-}$ & Fark & $S d$ & $t$ & $p$ \\
\hline \multirow[t]{2}{*}{ Zihinsel } & $\mathrm{K}_{1 \mathrm{Z}}$ & 149 & 44,67 & 1,14 & 320 & $-1,62$ & 104 \\
\hline & Erkek & 174 & 46,53 & 1,13 & & & \\
\hline \multirow[t]{2}{*}{ Davranışsal } & $\mathrm{K}_{12}$ & 149 & 45,36 & ,570 & 320 & $-1,93$ & ,056 \\
\hline & Erkek & 174 & 46,47 &, 575 & & & \\
\hline \multirow[t]{2}{*}{ Duygusal } & $\mathrm{K} 1 \mathrm{z}$ & 149 & 44,42 & 1,80 & 320 & $-2,38$ & ,019* \\
\hline & Erkek & 174 & 48,72 & 1,81 & & & \\
\hline \multirow[t]{2}{*}{ Toplam } & $\mathrm{K}_{1 \mathrm{z}}$ & 149 & 134,4 & $-7,26$ & 320 & $-2,06$ & ,039* \\
\hline & Erkek & 174 & 141,7 & $-7,26$ & & & \\
\hline \multicolumn{8}{|l|}{ Problem Çözme Becerisi } \\
\hline \multirow[t]{2}{*}{ Problem Çözme Algısı } & $\mathrm{K} 1 \mathrm{z}$ & 149 & 45,0 & 1,88 & 320 & $-1,171$ & 242 \\
\hline & Erkek & 174 & 47,2 & 1,87 & & & \\
\hline \multirow[t]{2}{*}{ İsteklilik/ Kararlılık } & $\mathrm{K}_{12}$ & 149 & 19,7 & 940 & 320 & $-2,562$ & , $011^{*}$ \\
\hline & Erkek & 174 & 47,2 & 1,87 & & & \\
\hline \multirow[t]{2}{*}{ Toplam Puan } & $\mathrm{K} 1 \mathrm{z}$ & 149 & 64,79 & 2,802 & 320 & $-1,645$ & 101 \\
\hline & Erkek & 174 & 69,40 & 2,805 & & & \\
\hline
\end{tabular}

${ }^{*} p<.05$

Tablo 3.'de, ergenin cinsiyetine göre iletişim becerileri incelendiğinde kız ve erkek ergenler arasında iletişim becerilerinin Zihinsel ve Davranışsal alt boyutları açısından anlamlı fark görülmezken ( $\mathrm{p}>$.05), Duygusal alt boyut puanında $\left(X_{\mathrm{K}_{\mathrm{z}}}=44.42, X_{\text {Erkek }}=48.72, \mathrm{t}=-2.38, \mathrm{p}<.05\right)$ ve iletişim becerileri toplam puanında $\left(X_{\mathrm{K}_{12}}=134.4662, X_{\text {Erkek }}=141.7299, \mathrm{t}=-2,06, \mathrm{p}<.05\right)$ farkın erkeklerin lehine anlamlı olduğu görülmektedir. Ayrıca ergenin cinsiyetine göre problem çözme becerileri incelendiğinde kız ve erkek ergenler arasında problem çözme becerilerinin problem çözme algısı alt boyutu ve toplam puan açısından anlamlı fark görülmezken ( $>$ > .05), İsteklilik ve kararlılık algisı alt boyutunda $\left(X_{\mathrm{K}_{12}}=19,7, X_{\text {Erkek }}=22,1, \mathrm{p}<.05\right)$ farkın erkeklerin lehine anlamlı olduğu görülmektedir. 
Tablo 4. Ergenin Sınıf Düzeyine Göre İletişim ve Problem Çözme Becerilerine İlişkin T Testi Sonuçları

\begin{tabular}{|c|c|c|c|c|c|c|c|}
\hline İletişim Becerisi & Grup & $N$ & $X^{-}$ & Fark & $\mathrm{Sd}$ & $t$ & $p$ \\
\hline \multirow{2}{*}{ Zihinsel } & 7. sinif & 158 & 41,19 & 1,14 & 320 & $-8,37$ &, $000^{* *}$ \\
\hline & 8. sinif & 165 & 49,87 & 1,13 & & & \\
\hline \multirow[t]{2}{*}{ Davranışsal } & 7. sinif & 158 & 43,51 &, 570 & 320 & $-9,31$ &, $000^{* *}$ \\
\hline & 8. sinif & 165 & 48,25 &, 575 & & & \\
\hline \multirow{2}{*}{ Duygusal } & 7. sinif & 158 & 39,45 & 1,80 & 320 & $-8,67$ &, $000^{* *}$ \\
\hline & 8. sinif & 165 & 53,61 & 1,81 & & & \\
\hline \multirow[t]{2}{*}{ Toplam } & 7. sinif & 158 & 124,1 & $-7,26$ & 320 & $-8,74$ &, $000^{* *}$ \\
\hline & 8. sinif & 165 & 151,7 & $-7,26$ & & & \\
\hline \multicolumn{8}{|l|}{ Problem Çözme Becerisi } \\
\hline \multirow{2}{*}{ Problem Çözme Alg1sı } & 7. sinif & 158 & 38,70 & 1,693 & 321 & $-8,645$ &, $000^{* *}$ \\
\hline & 8. sinif & 165 & 53,33 & 1,695 & & & \\
\hline \multirow[t]{2}{*}{ İsteklilik/ Kararlılık } & 7. sinif & 158 & 17,74 & 8750 & 321 & $-7,298$ &, $000^{* *}$ \\
\hline & 8. sinif & 165 & 24,13 & ,8726 & & & \\
\hline \multirow[t]{2}{*}{ Toplam } & 7. sinif & 158 & 56,44 & 2,546 & 321 & $-8,255$ &, $000^{* *}$ \\
\hline & 8. sinif & 165 & 77,47 & 2,545 & & & \\
\hline İletişim Becerisi & Grup & $N$ & $X^{-}$ & Fark & $\mathrm{Sd}$ & $t$ & $p$ \\
\hline \multirow[t]{2}{*}{ Zihinsel } & 7. sinif & 158 & 41,19 & 1,14 & 320 & $-8,37$ &, $000^{* *}$ \\
\hline & 8. sinif & 165 & 49,87 & 1,13 & & & \\
\hline \multirow[t]{2}{*}{ Davranışsal } & 7. sinif & 158 & 43,51 &, 570 & 320 & $-9,31$ &, $000^{* *}$ \\
\hline & 8. sinif & 165 & 48,25 &, 575 & & & \\
\hline \multirow[t]{2}{*}{ Duygusal } & 7. sinif & 158 & 39,45 & 1,80 & 320 & $-8,67$ &, $000^{* *}$ \\
\hline & 8. sinif & 165 & 53,61 & 1,81 & & & \\
\hline \multirow[t]{2}{*}{ Toplam } & 7. sinif & 158 & 124,1 & $-7,26$ & 320 & $-8,74$ &, $000^{* *}$ \\
\hline & 8. sinif & 165 & 151,7 & $-7,26$ & & & \\
\hline \multicolumn{8}{|l|}{ Problem Çözme Becerisi } \\
\hline \multirow[t]{2}{*}{ Problem Çözme Algısı } & 7. sinif & 158 & 38,70 & 1,693 & 321 & $-8,645$ &, $000^{* *}$ \\
\hline & 8. sinif & 165 & 53,33 & 1,695 & & & \\
\hline \multirow[t]{2}{*}{ İsteklilik/ Kararlılık } & 7. sinif & 158 & 17,74 & 8750 & 321 & $-7,298$ &, $000^{* *}$ \\
\hline & 8. sinif & 165 & 24,13 & ,8726 & & & \\
\hline \multirow[t]{2}{*}{ Toplam } & 7. sinif & 158 & 56,44 & 2,546 & 321 & $-8,255$ &, $000^{* *}$ \\
\hline & 8. sinif & 165 & 77,47 & 2,545 & & & \\
\hline
\end{tabular}

${ }^{* *} p<.001$

Tablo 4.'de, 7. ve 8. sınıfa devam eden ergenlerin iletişim becerileri puanları incelendiğinde; İletişim Becerilerinin Zihinsel $\left(X_{7 \text {. smif }}^{-}=41.19, X_{8 \text { smff }}=49.87, \mathrm{t}=-8.37, \mathrm{p}<.01\right)$, Davranışsal $\left(X_{7 \text {. sinf }}\right.$ $\left.=43.51, X_{8 . ~ s m i f}=48.25, t=-9.31, p<.01\right)$, Duygusal Alt Boyut $\left(X_{7 . ~ s m i f}=39,45, X_{8 . ~ s m i f}=53,61, t=-8,67\right.$, $\mathrm{p}<.01)$ ve Toplam Puanda $\left(X_{7 \text { smif }}=124,1, X_{8 \text { s smif }}=151,7, \mathrm{t}=-8,74, \mathrm{p}<.01\right)$ 8. Sinifa devam eden ergenler lehine anlamlı bir farklılık saptanmıştır. Ayrıca, ergenin öğrenim düzeyine göre problem çözme becerileri incelendiğinde 7. sınıf ve 8. sınıf ergenler arasında problem çözme becerilerinin alt boyutlarında ve toplam puanlarında 8 . Sınıfların lehine yüksek düzeyde anlamlı farklılık olduğu belirlenmiştir $\left(X_{8}^{-}\right.$s smif, Problem Çözme Algııı $=53.33, X_{8}^{-}$. smif, isteklilik/ Kararllık $=24.13$, $\left.X_{8 . \text { sinf, } \text { Toplam }}^{-}=77,47\right)$. 
Tablo 5. Ergenin Doğum Sırasına Göre İletişim Becerilerine İlişkin Betimsel Sonuçlar

\begin{tabular}{llllllll}
\hline İletişim & Doğum Sırasi & $N$ & $X$ & ss & $\begin{array}{l}\text { Varya } \\
\text { ns }\end{array}$ & Min. & Max. \\
\hline Zihinsel & İlk çocuk & 69 & 50,855 & 9,1028 & 82,86 & 30,00 & 67,00 \\
& İkinci çocuk & 190 & 47,510 & 9,4956 & 90,16 & 30,00 & 63,00 \\
& Üçüncü çocuk & 54 & 34,492 & 3,2670 & 10,67 & 30,00 & 40,00 \\
& Dördüncü çocuk & 10 & 32,231 & 11,225 & 126,00 & 30,00 & 39,00 \\
& Toplam & 323 & 45,680 & 10,247 & 105,00 & 30,00 & 67,00 \\
\hline Davranışsal & İlk çocuk & 69 & 48,652 & 4,3005 & 18,494 & 38,00 & 55,00 \\
& İkinci çocuk & 190 & 47,089 & 4,3324 & 18,769 & 38,00 & 55,00 \\
& Üçüncü çocuk & 54 & 39,619 & 2,3991 & 5,755 & 38,00 & 44,00 \\
& Dördüncü çocuk & 10 & 35,458 & 2,6547 & 7,0474 & 38,00 & 42,00 \\
& Toplam & 323 & 45,962 & 5,1269 & 26,285 & 38,00 & 55,00 \\
\hline Duygusal & İlk çocuk & 69 & 55,115 & 1,6587 & 2,7512 & 23,00 & 75,00 \\
& İkinci çocuk & 190 & 49,900 & 1,0756 & 1,1569 & 23,00 & 75,00 \\
& Üçüncü çocuk & 54 & 28,079 &, 65281 &, 4261 & 23,00 & 38,00 \\
& Dördüncü çocuk & 10 & 25,659 &, 58354 &, 3405 & 23,00 & 35,00 \\
& Toplam & 323 & 46,748 &, 90575 &, 8203 & 23,00 & 75,00 \\
\hline Toplam & İlk çocuk & 69 & 154,62 & 27,106 & 734,73 & 95,00 & 197,00 \\
& İkinci çocuk & 190 & 144,50 & 28,460 & 809,97 & 95,00 & 193,00 \\
& Üçüncü çocuk & 54 & 102,19 & 9,8420 & 96,864 & 95,00 & 121,00 \\
& Dördüncü çocuk & 10 & 100,39 & 6,8547 & 46,986 & 95,00 & 118,00 \\
\hline
\end{tabular}

Tablo 5 incelendiğinde ergenlerin doğum sırasına göre iletişim becerileri puanlarına ilişkin betimsel istatistikleri incelenmiştir. İletişim becerilerinin alt boyutlarına ve toplama ilişkin puan ortalamalarına bakıldığında tüm alt boyutlarda ve toplam puanda doğum sirası yükseldikçe puan ortalamalarının anlamlı şekilde düştügü görülmektedir. Tüm boyutlarda ilk çocukların en yüksek puan ortalamasına sahip olduğu göze çarpmaktadır ( $X_{\text {Zihinsel, Tek çocuk }}=50,855 ; X_{\text {Davranıssal, Tek }}$ çocuk $\left.=48,652 ; X_{\text {Duygusal, Tek Çocuk }}=55,115 ; X_{\text {Toplam, Tek Çocuk }}=154,62\right)$. İletişim becerileri puanlarının doğum sırasına göre karşılaştırıldığı ANOVA testi sonuçlarına tablo 6' da yer verilmiştir.

Tablo 6. Ergenin Kardeş Sayısına Göre İletişim ve Problem Çözme Becerilerine İlişkin Anova Testi Sonuçları

\begin{tabular}{|c|c|c|c|c|c|c|c|}
\hline İletişim Becerisi & Grup & KT & $S d$ & $\mathrm{KO}$ & $F$ & $p$ & Fark \\
\hline \multirow[t]{3}{*}{ Zihinsel } & Gruplar arası & 24499,8 & 2 & 12249,935 & \multirow[t]{3}{*}{420,513} & \multirow[t]{3}{*}{, $000^{* *}$} & \multirow{3}{*}{$\begin{array}{l}1>3>4 \\
2>3>4\end{array}$} \\
\hline & Gruplar İçi & 9321,89 & 321 & 29,131 & & & \\
\hline & Toplam & 33821,7 & 323 & & & & \\
\hline \multirow[t]{3}{*}{ Davranışsal } & Gruplar arası & 6056,82 & 2 & 3028,411 & \multirow[t]{3}{*}{396,528} & \multirow[t]{3}{*}{, $000^{* *}$} & \multirow{3}{*}{$\begin{array}{l}1>3>4 \\
2>3>4\end{array}$} \\
\hline & Gruplar İçi & 2443,94 & 321 & 7,637 & & & \\
\hline & Toplam & 8500,76 & 323 & & & & \\
\hline \multirow[t]{3}{*}{ Duygusal } & Gruplar arası & 63082,91 & 2 & 31541,456 & \multirow[t]{3}{*}{453,101} & \multirow[t]{3}{*}{, $000^{* *}$} & \multirow{3}{*}{$\begin{array}{l}1>3>4 \\
2>3>4\end{array}$} \\
\hline & Gruplar İçi & 22275,9 & 321 & 69,612 & & & \\
\hline & Toplam & 85358,8 & 323 & & & & \\
\hline Toplam & Gruplar arası & 235573,28 & 2 & 117786,640 & 453,500 &, $000^{* *}$ & \\
\hline
\end{tabular}




\begin{tabular}{|c|c|c|c|c|c|c|c|}
\hline & Gruplar İçi & 83112,87 & 321 & 259,728 & & & $1>3>4$, \\
\hline & Toplam & 318686,15 & 323 & & & & $2>3>4$ \\
\hline \multicolumn{8}{|c|}{ Problem Çözme Becerisi } \\
\hline \multirow{3}{*}{$\begin{array}{l}\text { Problem Çözme } \\
\text { Alg1sı }\end{array}$} & Gruplar arası & 66267,393 & 2 & 33215,9 & \multirow{3}{*}{$\begin{array}{l}422,867 \\
460,177\end{array}$} & \multirow[t]{3}{*}{, $000^{* *}$} & \multirow{3}{*}{$\begin{array}{l}1>3>4, \\
2>3>4\end{array}$} \\
\hline & Gruplar İçi & 25073,319 & 321 & 78,549 & & & \\
\hline & Toplam & 91340,712 & 323 & & & & \\
\hline \multirow{3}{*}{$\begin{array}{l}\text { İsteklilik/ } \\
\text { Kararlılık }\end{array}$} & Gruplar arası & 17233,8 & 2 & 8616,94 & \multirow{3}{*}{459,492} & \multirow[t]{3}{*}{, $000^{* *}$} & \multirow{3}{*}{$\begin{array}{l}1>3>4, \\
2>3>4\end{array}$} \\
\hline & Gruplar İçi & 5992,09 & 321 & 18,725 & & & \\
\hline & Toplam & 23225,9 & 323 & & & & \\
\hline \multirow[t]{3}{*}{ Toplam } & Gruplar arası & 151085,7 & 2 & 75542,883 & \multirow[t]{3}{*}{422,867} & \multirow[t]{3}{*}{, $000^{* *}$} & \multirow{3}{*}{$\begin{array}{l}1>3>4, \\
2>3>4\end{array}$} \\
\hline & Gruplar İçi & 52609,7 & 321 & 164,405 & & & \\
\hline & Toplam & 203695,48 & 323 & & & & \\
\hline
\end{tabular}

$* * p<.001$

Tablo 6.'da ergenlerin kardeş sayısına göre iletişim ve problem çözme becerilerine ilişkin Anova sonuçları görülmektedir. Tabloda "fark" kısmında yer alan, 1= tek çocuğu, 2=iki çocuğu, $3=$ üç çocuğu, $4=$ dört çocuğu temsil etmektedir. Her iki ölçek içinde oluşturulmuş gruplar arasındaki farkın yüksek düzeyde anlamlı olduğu sonucuna ulaşılmıştır (FZihinsel(2-321) $=420.513, \mathrm{~F}$ Davranissal $(2-321)=396.528, \mathrm{~F}$ Duygusal $(2-321)=453.101, \mathrm{~F}$ Toplam $(2-321)=453.500, \mathrm{~F}$ Problem Çözme Algısı $(2-321)=422.867, \mathrm{~F}$ isteklilik/ Kararllık $(2-321)=460.177, \mathrm{~F}$ Toplam $(2-321)=459.492, \mathrm{p}<.001)$. Gruplar arasındaki farkın hangi gruptan kaynaklandığını belirlemek için yapılan Tukey testi sonucunda her iki ölçek için de tek çocuklarla 1 kardeşi olan çocuklar arasında anlamlı ilişki görülmezken kardeş sayısı arttıkça alınan puanlarda düşüş olduğu görülmektedir $(\mathrm{p}<.001)$.

Tablo 7. Ergenin Doğum Strasına Göre Illetişim ve Problem Çözme Becerilerine İlişkin Anova Testi Sonuçları

\begin{tabular}{|c|c|c|c|c|c|c|c|}
\hline İletişim Becerisi & Grup & $K t$ & $S d$ & Ko & $F$ & $P$ & Fark \\
\hline \multirow[t]{3}{*}{ Zihinsel } & Gruplar Arası & 10595,5 & 3 & 5297,759 & 72,57 &, $000^{* *}$ & $1>2>3>4$ \\
\hline & Gruplar İçi & 23357,6 & 320 & 72,993 & & & \\
\hline & Toplam & 33953,1 & 323 & & & & \\
\hline \multirow[t]{3}{*}{ Davranışsal } & Gruplar Arası & 3336,19 & 3 & 1668,09 & 103,3 &, $000^{* *}$ & $1>2>3>4$ \\
\hline & Gruplar İçi & 5164,56 & 320 & 16,139 & & & \\
\hline & Toplam & 8500,76 & 323 & & & & \\
\hline \multirow[t]{3}{*}{ Duygusal } & Gruplar Arası & 29063,4 & 3 & 14531,74 & 82,85 &, $000^{* *}$ & $1>2>3>4$ \\
\hline & Gruplar İçi & 56121,9 & 320 & 175,381 & & & \\
\hline & Toplam & 85185,4 & 323 & & & & \\
\hline \multirow[t]{3}{*}{ Toplam } & Gruplar Arası & 109657,360 & 3 & 54828,68 & 83,902 &, $000^{* *}$ & $1>2>3>4$ \\
\hline & Gruplar İçi & 209114,312 & 320 & 653,482 & & & \\
\hline & Toplam & 318771,672 & 323 & & & & \\
\hline \multicolumn{8}{|c|}{ Problem Çözme Becerisi } \\
\hline \multirow{2}{*}{$\begin{array}{l}\text { Problem Çözme } \\
\text { Algisı }\end{array}$} & Gruplar Arası & 30812,8 & 3 & 15406,4 & 81,1 &, $000^{* *}$ & $1>2>3>4$ \\
\hline & Gruplar İçi & 60754,7 & 320 & 189,859 & & & \\
\hline
\end{tabular}




\begin{tabular}{|c|c|c|c|c|c|c|c|}
\hline & Toplam & 91567,5 & 323 & & & & \\
\hline \multirow{3}{*}{$\begin{array}{l}\text { İsteklilik/ } \\
\text { Kararlılık }\end{array}$} & Gruplar Arası & 5986,61 & 3 & 2993,30 & \multirow[t]{3}{*}{55,8} & \multirow[t]{3}{*}{, $000^{* *}$} & \multirow{3}{*}{$1>2>3>4$} \\
\hline & Gruplar İçi & 17144,3 & 320 & 53,576 & & & \\
\hline & Toplam & 23130,9 & 323 & & & & \\
\hline \multirow[t]{3}{*}{ Toplam } & Gruplar Arası & 63897,8 & 3 & 31948,9 & \multirow[t]{3}{*}{73,1} & \multirow[t]{3}{*}{, $000^{* *}$} & \multirow[t]{3}{*}{$1>2>3>4$} \\
\hline & Gruplar İçi & 139797,6 & 320 & 436,868 & & & \\
\hline & Toplam & 203695,4 & 323 & & & & \\
\hline
\end{tabular}

${ }^{* *} p<.001$

Tablo 7.'de ergenlerin doğum sırasına göre İletişim ve Problem Çözme Becerilerine ilişkin Anova sonuçları görülmektedir. Tabloda "fark" kısmında yer alan, 1= ilk çocuğu, 2= ikinci çocuğu, 3=üçüncü çocuğu, 4= dördüncü çocuğu temsil etmektedir. Her iki beceride de oluşturulmuş gruplar arasındaki farkın yüksek düzeyde anlamlı olduğu sonucuna ulaşılmıştır (FZihinsel(3-320) $=72,579, \mathrm{~F}$ Davranışsal(3-320) $=103,356, \mathrm{~F}$ Duygusal(3-320) $=82,858, \mathrm{~F}$ Toplam (3-320) $=83,902, \mathrm{~F}$ Problem Çözme Algııı (3-320) $=81,147, \mathrm{~F}$ isteklilik/ Kararllık $(3-320)=55,870, \mathrm{~F}$ Toplam (3-320) $=73,132, \mathrm{p}<.001)$. Gruplar arasındaki farkın hangi gruptan kaynaklandığını belirlemek için yapılan Tukey testi sonucunda çocuğun doğum sırası arttıkça ölçeklerden aldıkları puanlarda düşüş olduğu ve bu düşüşün istatiksel açıdan yüksek düzeyde anlamlı olduğu belirlenmiştir $(\mathrm{p}<.001)$.

Tablo 8. Ergenin Anne Öğrenim Düzeyine Göre İletişim ve Problem Çözme Becerilerine İlişkin Anova Testi Sonuçları

\begin{tabular}{|c|c|c|c|c|c|c|c|}
\hline $\begin{array}{l}\text { İletişim } \\
\text { Becerisi }\end{array}$ & Grup & KT & $S d$ & $K O$ & $F$ & $p$ & Fark \\
\hline \multirow[t]{3}{*}{ Zihinsel } & Gruplar arası & 20946,272 & 4 & 5236,568 & \multirow{3}{*}{$\begin{array}{l}128,0 \\
27\end{array}$} & \multirow[t]{3}{*}{, $000^{* *}$} & \multirow{3}{*}{$\begin{array}{l}5>3>2>1 \\
4>3>2>1\end{array}$} \\
\hline & Gruplar İçi & 13006,886 & 319 & 40,902 & & & \\
\hline & Toplam & 33953,158 & 323 & & & & \\
\hline \multirow[t]{3}{*}{ Davranışsal } & Gruplar arası & 5279,085 & 4 & 1319,771 & \multirow{3}{*}{$\begin{array}{l}130,2 \\
70\end{array}$} & \multirow[t]{3}{*}{, $000^{* *}$} & \multirow{3}{*}{$\begin{array}{l}5>3>2>1 \\
4>3>2>1\end{array}$} \\
\hline & Gruplar İçi & 3221,676 & 319 & 10,131 & & & \\
\hline & Toplam & 8500,762 & 323 & & & & \\
\hline \multirow[t]{3}{*}{ Duygusal } & Gruplar arası & 54754,990 & 4 & 13688,748 & \multirow{3}{*}{$\begin{array}{l}143,0 \\
48\end{array}$} & \multirow[t]{3}{*}{, $000^{* *}$} & \multirow{3}{*}{$\begin{array}{l}5>3>2>1 \\
4>3>2>1\end{array}$} \\
\hline & Gruplar İçi & 30430,428 & 319 & 95,693 & & & \\
\hline & Toplam & 85185,418 & 323 & & & & \\
\hline \multirow[t]{3}{*}{ Toplam } & Gruplar arası & 203477,30 & 4 & 50869,327 & \multirow{3}{*}{$\begin{array}{l}140,3 \\
06\end{array}$} & \multirow[t]{3}{*}{, $000^{* *}$} & \multirow{3}{*}{$\begin{array}{l}5>3>2>1 \\
4>3>2>1\end{array}$} \\
\hline & Gruplar İçi & 115294,36 & 319 & 362,561 & & & \\
\hline & Toplam & 318771,67 & 323 & & & & \\
\hline \multicolumn{8}{|c|}{ Problem Çözme Becerisi } \\
\hline \multirow{3}{*}{$\begin{array}{l}\text { Problem } \\
\text { Çözme Algısı }\end{array}$} & Gruplar arası & 60759,8 & 4 & 65027,020 & \multirow[t]{3}{*}{156,7} & \multirow[t]{3}{*}{, $000^{* *}$} & $5>4>3>2>$ \\
\hline & Gruplar İçi & 30807,7 & 318 & 184,208 & & & 1 \\
\hline & Toplam & 91567,5 & 322 & & & & \\
\hline \multirow{3}{*}{$\begin{array}{l}\text { İsteklilik/ } \\
\text { Kararlılık }\end{array}$} & Gruplar arası & 14508,9 & 4 & 3627,22 & \multirow[t]{3}{*}{133,7} & \multirow[t]{3}{*}{, $000^{* *}$} & $5>4>3>2>$ \\
\hline & Gruplar İçi & 8622,06 & 318 & 27,113 & & & \multirow[t]{2}{*}{1} \\
\hline & Toplam & 23130,9 & 322 & & & & \\
\hline
\end{tabular}




\begin{tabular}{|c|c|c|c|c|c|c|c|}
\hline \multirow[t]{3}{*}{ Toplam } & Gruplar arası & 260108,08 & 4 & 65027,020 & 154,6 &, $000^{* *}$ & $5>4>3>2>$ \\
\hline & Gruplar İçi & 58578,073 & 319 & 184,208 & & & \\
\hline & Toplam & 318686,15 & 323 & & & & \\
\hline
\end{tabular}

${ }^{* *} p<.001$

Tablo 8.'de ergenlerin anne öğrenim düzeyine göre iletişim ve problem çözme becerilerine ilişkin Anova sonuçları görülmektedir. Tabloda "fark" kısmında yer alan, $5=$ lisans üstü eğitime sahip olan anneleri, 4=lisans mezunu anneleri, 3=lise mezunu anneleri, 2=ortaokul mezunu anneleri ve $1=$ ilkokul mezunu anneleri temsil etmektedir. İletişim becerileri puanlarına uygulanan Tukey testinde lisans mezunu anneler ile lisansüstü mezuniyeti olan anneler arasında anlamlı fark bulunmamışken anne öğrenim düzeyi arttıkça alınan puanlarda artış olduğu ve bu artışın istatiksel açıdan yüksek düzeyde anlamlı bir fark olduğu belirlenmiştir (FZihinsel(4-319) $=309,088, \mathrm{~F}$ Davranıssal(4-319) $=351,528, \mathrm{~F}$ Duygusal(4-319) $=345,971$, F Toplam (4-319) $=353,009, \mathrm{p}<.001)$. Problem Çözme Becerilerine ilişkin Anova sonuçlarında ise oluşturulmuş gruplar arasındaki farkın anlamlı olduğu sonucuna ulaşılmıştır (F Problem çözme Algııı (4-318) $=156.792$, $\mathrm{F}$ isteklilik/ Kararllık $(4-318)=133.780, \mathrm{~F}$ Toplam (4-318) $=154.673, \mathrm{p}<.001)$. Gruplar arasındaki farkın hangi gruptan kaynaklandığını belirlemek için yapılan Tukey testi sonucunda anne öğrenim düzeyi yükseldikçe alınan puanlarda artış olduğu sonucuna ulaşılmıştır $(\mathrm{p}<.001)$.

Tablo 9. Ergenin Baba Öğrenim Düzeyine Göre İletişim ve Problem Çözme Becerilerine İlişkin Anova Testi Sonuçları

\begin{tabular}{|c|c|c|c|c|c|c|c|}
\hline $\begin{array}{l}\text { İletişim } \\
\text { Becerisi }\end{array}$ & Grup & KT & $S d$ & KO & $F$ & $p$ & Fark \\
\hline \multirow[t]{3}{*}{ Zihinsel } & Gruplar arası & 26902,267 & 4 & 6725,567 & \multirow[t]{3}{*}{309,0} & \multirow[t]{3}{*}{, $000^{* *}$} & $5>3>2>1$ \\
\hline & Gruplar İçi & 6919,498 & 319 & 21,759 & & & $4>3>2>1$ \\
\hline & Toplam & 33821,765 & 323 & & & & \\
\hline \multirow[t]{3}{*}{ Davranışsal } & Gruplar arası & 6932,856 & 4 & 1733,214 & \multirow[t]{3}{*}{351,5} & \multirow[t]{3}{*}{, $000^{* *}$} & $5>3>2>1$ \\
\hline & Gruplar İçi & 1567,906 & 319 & 4,931 & & & $4>3>2>1$ \\
\hline & Toplam & 8500,762 & 323 & & & & \\
\hline \multirow[t]{3}{*}{ Duygusal } & Gruplar arası & 69409,407 & 4 & 17352,352 & \multirow[t]{3}{*}{345,9} & \multirow[t]{3}{*}{, $000^{* *}$} & $5>3>2>1$ \\
\hline & Gruplar İçi & 15949,459 & 319 & 50,156 & & & $4>3>2>1$ \\
\hline & Toplam & 85358,867 & 323 & & & & \\
\hline \multirow[t]{3}{*}{ Toplam } & Gruplar arası & 260108,08 & 4 & 65027,020 & \multirow[t]{3}{*}{353,0} & \multirow[t]{3}{*}{, $000^{* *}$} & $5>3>2>1$ \\
\hline & Gruplar İçi & 58578,073 & 319 & 184,208 & & & $4>3>2>1$ \\
\hline & Toplam & 318686,15 & 323 & & & & \\
\hline \multicolumn{8}{|c|}{ Problem Çözme Becerisi } \\
\hline \multirow{3}{*}{$\begin{array}{l}\text { Problem } \\
\text { Çözme Alg1sı }\end{array}$} & Gruplar arası & 60759,8 & 4 & 15189,957 & \multirow[t]{3}{*}{156,7} & \multirow[t]{3}{*}{, $000^{* *}$} & \multirow[t]{3}{*}{$5>4>3>2>1$} \\
\hline & Gruplar İçi & 30807,7 & 318 & 96,880 & & & \\
\hline & Toplam & 91567,5 & 322 & & & & \\
\hline \multirow{3}{*}{$\begin{array}{l}\text { İsteklilik/ } \\
\text { Kararlılık }\end{array}$} & Gruplar arası & 14508,9 & 4 & 3627,227 & \multirow[t]{3}{*}{133,7} & \multirow[t]{3}{*}{, $000^{* *}$} & \multirow[t]{3}{*}{$5>4>3>2>1$} \\
\hline & Gruplar İçi & 8622,06 & 318 & 27,113 & & & \\
\hline & Toplam & 23130,9 & 322 & & & & \\
\hline
\end{tabular}




\begin{tabular}{|c|c|c|c|c|c|c|c|}
\hline \multirow[t]{3}{*}{ Toplam } & Gruplar arası & $\begin{array}{l}134542,46 \\
9\end{array}$ & 4 & 33635,617 & \multirow[t]{3}{*}{154,6} & \multirow[t]{3}{*}{, $000^{* *}$} & \multirow[t]{3}{*}{$5>4>3>2>1$} \\
\hline & Gruplar İçi & 69153,011 & 319 & 217,46 & & & \\
\hline & Toplam & 203695,48 & 323 & & & & \\
\hline
\end{tabular}

$* * 0.001$

Tablo 9.'da ergenlerin baba öğrenim düzeyine göre iletişim ve problem çözme becerilerine ilişkin Anova sonuçları görülmektedir. Tabloda "fark" kısmında yer alan, 5= lisans üstü eğitime sahip olan babaları, 4=lisans mezunu babaları, 3=lise mezunu babaları, 2=ortaokul mezunu babaları ve 1 =ilkokul mezunu babaları temsil etmektedir. İletişim becerileri puanlarında oluşturulmuş gruplar arasındaki farkın anlamlı olduğu sonucuna ulaşılmıştır $\left(\right.$ FZihinsel $(4-319)=128.027, F_{\text {Davranıssal }}(4-319)=130.270$, FDuygusal $(4-319)=143.048, F_{\text {Toplam }}(4-319)=$ $143.048, \mathrm{p}<.001)$. Gruplar arasındaki farkın hangi gruptan kaynaklandığını belirlemek için yapılan Tukey testi sonucunda lisans mezunu babalar ile lisansüstü mezun olan babaların çocukları arasında anlamlı bir fark olmazken lisans ve lisansüstü mezuniyeti olan babalar ile diğer babalar arasındaki farkın anlamlı olduğu saptanmıştır. Baba öğrenim düzeyi arttıkça alınan puanlarda artış olduğu görülmektedir ( $p<.001)$. Ergenlerin baba öğrenim düzeyine göre problem çözme becerilerine ilişkin Anova sonuçlarında ise gruplar arasındaki farkın yüksek düzeyde anlamlı olduğu sonucuna ulaşılmıştır (F Problem Çözme Algııı (4-318) =156.792, F issteklilik/Kararlılık $(4-318)=133.780, \mathrm{~F}$ Toplam $(4-318)=154.673, \mathrm{p}<.001)$. Gruplar arasındaki farkın hangi gruptan kaynaklandığını belirlemek için yapılan Tukey testi sonucunda baba öğrenim düzeyi yükseldikçe alınan puanlarda artış olduğu ve bu artışın istatiksel açıdan yüksek düzeyde anlamlı olduğu belirlenmiştir $(\mathrm{p}<.001)$.

Tablo 10. Ergenin Okul Öncesi Eğitim Alma Durumuna Göre İletişim Becerilerine İlişkin Betimsel Sonuçlar

\begin{tabular}{|c|c|c|c|c|c|c|c|}
\hline \multirow{2}{*}{$\begin{array}{l}\text { İletişim } \\
\text { Becerisi }\end{array}$} & Öncesi & $\mathrm{N}$ & $x$ & ss & Varyans & $\mathrm{Mi}$ & Max. \\
\hline & \multicolumn{5}{|l|}{ Eğitim Alma } & n. & \\
\hline \multirow{5}{*}{ Zihinsel } & Hayır & 52 & 32,40 & 2,52252 & 6,363 & 30,00 & 35,00 \\
\hline & Evet 1 yıl & 113 & 40,17 & 5,45473 & 29,754 & 30,00 & 54,00 \\
\hline & Evet 2 yil & 93 & 52,70 & 7,67064 & 58,838 & 37,00 & 63,00 \\
\hline & Evet 3 yıl ve üzeri & 65 & 55,56 & 4,58247 & 20,999 & 38,00 & 67,00 \\
\hline & Toplam & 323 & 45,63 & 10,2686 & 105,44 & 30,00 & 67,00 \\
\hline \multirow[t]{5}{*}{ Davranışsal } & Hayır & 52 & 38,00 & , 00000 & 00000 & 36,00 & 38,00 \\
\hline & Evet 1 yll & 113 & 43,93 & 2,72974 & 7,451 & 38,00 & 50,00 \\
\hline & Evet 2 yil & 93 & 49,26 & 3,13514 & 9,829 & 41,00 & 55,00 \\
\hline & Evet 3 yıl ve üzeri & 65 & 51,00 & 2,29129 & 5,25 & 43,00 & 55,00 \\
\hline & Toplam & 323 & 45,93 & 5,13808 & 26,399 & 38,00 & 55,00 \\
\hline \multirow[t]{5}{*}{ Duygusal } & Hayır & 52 & 25,07 & 2,01802 & 4,072 & 23,00 & 27,00 \\
\hline & Evet 1 yıl & 113 & 38,28 & 8,88264 & 78,901 & 23,00 & 60,00 \\
\hline & Evet 2 yil & 93 & 58,08 & 11,7359 & 137,73 & 34,00 & 75,00 \\
\hline & Evet 3 yıl ve üzeri & 65 & 62,27 & 7,20570 & 51,922 & 35,00 & 75,00 \\
\hline & Toplam & 323 & 46,68 & 16,2650 & 264,55 & 23,00 & 75,00 \\
\hline \multirow[t]{4}{*}{ Toplam } & Hayır & 52 & 100,3 & ,50450 & 0,2545 & 95,00 & 96,00 \\
\hline & Evet 1 yıl & 113 & 122,3 & 16,8552 & 284,09 & 95,00 & 164,00 \\
\hline & Evet 2 yıl & 93 & 160,0 & 22,3921 & 501,40 & 116,0 & 193,00 \\
\hline & Evet 3 yıl ve üzeri & 65 & 168,8 & 13,8024 & 190,50 & 116,0 & 197,00 \\
\hline
\end{tabular}


Tablo 10.'da Ergenlerin okul öncesi eğitim alma durumlarına göre iletişim becerileri puanlarına ilişkin betimsel istatistikleri incelenmiştir. İletişim becerilerinin alt boyutlarına ve toplama ilişkin puan ortalamalarına bakıldığında tüm alt boyutlarda ve toplam puanda ergenlerin okul öncesi eğitim süreleri artıkça puan ortalamalarının da arttığı görülmektedir. Tüm boyutlarda üç yıl ve üzeri okul öncesi eğitim alan çocukların en yüksek puan ortalamasına sahip olduğu göze çarpmaktadır ( $X$ Zihinsel, Evet 3 yıl ve üzeri $=4,58247$; $X$ Davranışsal, Evet 3 yıl ve üzeri =2,29129; X Duygusal, Evet 3 yıl ve üzeri =7,20570; $X$ Toplam, Evet 3 yıl ve üzeri $=13,8024$ ). İletişim becerileri puanlarının okul öncesi eğitim alma durumuna göre karşılaştırıldığı ANOVA testi sonuçlarına Tablo 11.'de yer verilmiştir.

Tablo 11. Ergenin Okul Öncesi Eğitim Alma Durumuna Göre İletişim ve Problem Çözme Becerilerine İlişkin Anova Testi Sonuçları

\begin{tabular}{|c|c|c|c|c|c|c|}
\hline İletişim Becerisi & Grup & KT & $S d$ & $\mathrm{KO}$ & $F$ & $p$ \\
\hline \multirow[t]{3}{*}{ Zihinsel } & Gruplar arası & 23539,079 & 3 & 7846,360 & 240,347 &, $000^{* *}$ \\
\hline & Gruplar İçi & 10414,079 & 319 & 32,646 & & \\
\hline & Toplam & 33953,158 & 322 & & & \\
\hline \multirow[t]{3}{*}{ Davranışsal } & Gruplar arası & 6425,916 & 3 & 2141,972 & 329,320 &, $000^{* *}$ \\
\hline & Gruplar İçi & 2074,846 & 319 & 6,504 & & \\
\hline & Toplam & 8500,762 & 322 & & & \\
\hline \multirow[t]{3}{*}{ Duygusal } & Gruplar arası & 60146,460 & 3 & 20048,820 & 255,425 &, $000^{* *}$ \\
\hline & Gruplar İçi & 25038,958 & 319 & 78,492 & & \\
\hline & Toplam & 85185,418 & 322 & & & \\
\hline \multirow[t]{3}{*}{ Toplam } & Gruplar arası & 228617,537 & 3 & 76205,846 & 269,646 &, $000^{* *}$ \\
\hline & Gruplar İçi & 90154,135 & 319 & 282,615 & & \\
\hline & Toplam & 318771,672 & 322 & & & \\
\hline $\begin{array}{l}\text { Problem } \\
\text { Becerisi }\end{array}$ & & & & & & \\
\hline \multirow[t]{3}{*}{ Problem Çözme Algısı } & Gruplar arası & 66288,859 & 3 & 22096,286 & 278,840 &, $000^{* *}$ \\
\hline & Gruplar İçi & 25278,726 & 319 & 79,244 & & \\
\hline & Toplam & 91567,585 & 322 & & & \\
\hline \multirow{3}{*}{ İsteklilik/ Kararlılık } & Gruplar arası & 15422,449 & 3 & 5140,816 & 212,741 &, $000^{* *}$ \\
\hline & Gruplar İçi & 7708,523 & 319 & 24,165 & & \\
\hline & Toplam & 23130,972 & 322 & & & \\
\hline \multirow[t]{3}{*}{ Toplam } & Gruplar arası & 145105,168 & 3 & 48368,389 & 263,346 &, $000^{* *}$ \\
\hline & Gruplar İçi & 58590,312 & 319 & 183,669 & & \\
\hline & Toplam & 203695,480 & 322 & & & \\
\hline
\end{tabular}

${ }^{* *} p<.001$

Tablo 11.'de ergenlerin okul öncesi eğitim alma durumuna göre İletişim ve problem çözme Becerilerine ilişkin Anova sonuçları görülmektedir. İletişim becerileri sonuçları incelendiğinde oluşturulmuş gruplar arasındaki farkın anlamlı olduğu sonucuna ulaşılmıştır (Fzihinsel(3-319) = 240.347, F Davranıssal(3-319) = 329.320, F Duygusal (3-319) $=255.425, \mathrm{~F}_{\text {Toplam }}(3-319)=269.646$, p $\left.<.001\right)$. Gruplar arasındaki farkın hangi gruptan kaynaklandığını belirlemek için yapılan Tukey testi sonucunda en düşük puanların hiç okul öncesi eğitim almayan ergenlerin puanları olduğu görülürken okul öncesi eğitim alma süresi arttıkça alınan puanların da arttığ1 sonucuna ulaşılmıştır $(\mathrm{p}<.001)$. Problem çözme becerilerine ilişkin Anova sonuçlarında ise oluşturulmuş 
gruplar arasındaki farkın anlamlı olduğu sonucuna ulaşılmıştır (F Problem Çözme Algısı (3-319) = 278.840, F isteklilik/Kararllık $(3-319)=212.741, \mathrm{~F}$ Toplam $(3-319)=263.346, \mathrm{p}<.001)$. Gruplar arasındaki farkın hangi gruptan kaynaklandığını belirlemek için yapılan Tukey testi sonucunda okul öncesi eğitim alma süresi arttıkça alınan puanların artarken, hiç okul öncesi eğitim almayan ergenlerin en düşük puanları aldığı belirlenmiştir. Puanlardaki farkın istatiksel açıdan yüksek düzeyde anlamlı olduğu saptanmıştır ( $\mathrm{p}<.001)$.

Tablo 12. Ergenlerin İletişim ve Problem Çözme Becerileri Arasındaki İlişkiye Yönelik Korelasyon Analizi

\begin{tabular}{|c|c|c|c|c|c|c|c|c|c|}
\hline & 苛 & Zihinsel & $\begin{array}{c}\text { Davranışsa } \\
1\end{array}$ & Duygusal & Toplam & 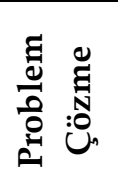 & Alg1 & $\begin{array}{l}\text { İsteklili } \\
\text { k/ } \\
\text { Kararlı1 } \\
\text { 1k }\end{array}$ & $\begin{array}{c}\text { Topla } \\
\text { m }\end{array}$ \\
\hline İletişim & $r$ & 1 & ,970** & , $981^{* *}$ & $992^{* *}$ & & , $991^{* *}$ & $962^{* *}$ & $988^{* *}$ \\
\hline \multirow{2}{*}{ Zihinsel } & $P$ & & ,000 & ,000 & ,000 & & ,000 & ,000 & ,000 \\
\hline & $N$ & 323 & 323 & 323 & 323 & & 323 & 323 & 323 \\
\hline \multirow{3}{*}{$\begin{array}{c}\text { Davranışsa } \\
1\end{array}$} & $r$ & ,970** & 1 & , $978^{* *}$ & $985^{* *}$ & & , $980^{* *}$ & , $945^{* *}$ & $976^{* *}$ \\
\hline & $P$ & ,000 & & ,000 & ,000 & & ,000 & ,000 & ,000 \\
\hline & $N$ & 323 & 323 & 323 & 323 & & 323 & 323 & 323 \\
\hline \multirow{3}{*}{ Duygusal } & $r$ & , $981^{* *}$ & , $978^{* *}$ & 1 & , $997^{* *}$ & & ,987** & , $985^{* *}$ & $994^{* *}$ \\
\hline & $P$ & ,000 & ,000 & & ,000 & & ,000 & ,000 & ,000 \\
\hline & $N$ & 323 & 323 & 323 & 323 & & 323 & 323 & 323 \\
\hline \multirow{3}{*}{ Toplam } & $r$ &, $992^{* * *}$ & , $985^{* *}$ & , $997^{* *}$ & 1 & & , $994^{* *}$ & ,978** & $996^{* *}$ \\
\hline & $P$ & ,000 & ,000 & ,000 & & & ,000 & ,000 &, 000 \\
\hline & $N$ & 323 & 323 & 323 & 323 & & 323 & 323 & 323 \\
\hline $\begin{array}{c}\text { Problem } \\
\text { Çözme }\end{array}$ & $r$ & , $991^{* * *}$ & , $980^{* *}$ & ,987** & $994^{* *}$ & & 1 & ,967* & $996^{* *}$ \\
\hline \multirow{2}{*}{ Alg1 } & $P$ & ,000 & ,000 & ,000 & ,000 & & & ,000 & ,000 \\
\hline & $N$ & 323 & 323 & 323 & 323 & & 323 & 323 & 323 \\
\hline \multirow{3}{*}{$\begin{array}{c}\text { İsteklilik/K } \\
\text { ararlılık }\end{array}$} & $r$ &, $962^{* * *}$ & , $945^{* *}$ & , $985^{* * *}$ & $978^{* *}$ & & , $967^{* * *}$ & 1 & $985^{* *}$ \\
\hline & $P$ &, 000 & ,000 & , 000 & ,000 & & ,000 & & ,000 \\
\hline & $N$ & 323 & 323 & 323 & 323 & & 323 & 323 & 323 \\
\hline \multirow{3}{*}{ Toplam } & $r$ & , $988^{* *}$ & , $976^{* *}$ & , $994^{* *}$ & $996^{* *}$ & & , $996^{* *}$ & , $985^{* *}$ & 1 \\
\hline & $P$ &, 000 & ,000 & ,000 & ,000 & & ,000 & ,000 & \\
\hline & $N$ & 323 & 323 & 323 & 323 & & 323 & 323 & 323 \\
\hline
\end{tabular}

${ }^{* *} p<.001$

Tablo 12.'de çalışmaya dâhil edilen ergenlerin "İletişim Becerileri Envanteri" ve "İlköğretim Öğrencileri İçin Problem Çözme Becerilerine Yönelik Alg1 Ölçeği”nden elde ettiği alt boyut ve toplam puanlar arasındaki ilişkiye yönelik bulgulara yer verilmiştir. Verilerin normal dağılım gösteren puanlardan oluşmasından dolayı ölçekler arasındaki ilişki incelenirken Pearson Korelasyon Katsayısı (r) hesaplanmıştır. Ölçeklerin alt boyutları ve toplam puanları arasındaki ilişkiye bakıldığında tüm puanlarla anlamlı yüksek düzeyde anlamlı ilişki olduğu görülmektedir $(\mathrm{p}<, 001)$. 


\section{TARTIŞMA, SONUÇ ve ÖNERILER}

Çalışma sonuçları, zihinsel, davranışsal ve duygusal boyutlarından oluşan "İletişim Becerileri Envanteri" ile problem çözme becerilerine yönelik alg1 ve problem çözme becerilerine yönelik isteklilik ve kararlılık algısı boyutlarından oluşan “ỉlköğretim Öğrencileri İçin Problem Çözme Becerilerine Yönelik Algı Ölçeği" ne ilişkin bulgular ilgili literatür yardımıyla yorumlanarak tartışılmıştır.

Doğumla birlikte farklı dönemlerden geçmeye başlayan insan hayat boyu gelişimine devam eder ve bu gelişim sürecinin kadınlar ve erkekler açısından farklı yaşandığı söylenebilir (Bolat, 2010). Erikson (1982) değişimin çok hızlı yaşandığ 1 ergenlik döneminin özelliklerinden bahsederken, aileden duygusal bağımsızlığın kazanıldı̆̆ı, cinsiyete uygun sosyal rollerin geliştiği bir süreç olduğuna vurgu yapmıştır. Araştırmaya dâhil edilen ergenlerin cinsiyete göre İletişim Becerileri Envanterinden aldıkları puanlar incelendiğinde zihinsel ve davranışsal boyutlarda anlamlı bir fark yokken duygusal boyutta ve toplam puanda erkeklerin lehine anlamlı farklılık olduğu saptanmıştır. Gesell (1957) ergenlikte cinsiyet faktörünün etkisinden bahsederken kızların erkeklerden 2 yıl önce bu süreci yaşamaya başladıklarını söylemiştir. Çalışmamızda duygusal boyutta saptanan bu farklılığın nedeni Gesell'in de belirttiği gibi farklı duygularla tanışılan ergenlik dönemine kızların erkeklerden daha erken girmesindir. Çünkü kızlar ergenliğe erken girdikleri için bu dönemde duygusal sıkıntılarla ve farklılıklarla boğuşmaktadır. Yaşanan bu sıkıntılı süreç kızları daha depresif ve kaygılı yapabilmektedir (Eldeleklioğlu, 2008). Ayrıca Aydın (2015) yaptığı çalışmada kızların duygusal özerklik açısından erkeklere göre daha düşük puanlar aldığını belirlemiştir. Bu nedenle uygulanan iletişim becerileri ölçeğinde duygusal boyutta daha düşük puanlar aldığı düşünülmektedir.

Araştırmaya dâhil edilen ergenlerin iletişim becerileri puanlarının öğrenim gördükleri sınıf düzeyi dikkate alınarak incelendiğinde tüm alt boyutlarda ve toplam puanda 8 . sinıfların 7 . sınıflara göre puan ortalamalarında artış olduğu görülmektedir. Bu bulgu, pek çok araştırma sonucu ile desteklenmektedir (Akçam, 2019; Gürhan, Meriç, Kaya, Turan ve Kabataş 2018; McMaster ve ark. 2002; Tekiner, 1997 ). Tekiner (1997)'in de vurguladığ1 gibi bilişsel gelişim yaşla birlikte gelişmeye devam etmektedir. İletişim becerisinin bilişsel işlevlerle direkt ilişkili olduğu düşünüldüğünde yaşla beraber iletişim becerilerinin de ilerlemiş olması gelişimin bir parçası olarak kabul edilebilir. Akçam (2019) tarafından yapılan çalışmada ortaokul öğrencilerinin iletişim becerileri ve Türkçe dersine yönelik tutumları çeşitli değişkenler açısından incelenmiştir. 5, 6, 7 ve 8. sınıflarda öğrenim gören ergenlerle çalışılan bu araştırma sonucunda öğrencilerin sınıf düzeyleri arttıkça iletişim becerilerinin de ilerlediği sonucuna ulaşılmıştır. Çalışmamızda da benzer şekilde ergenliğin ilk yıllarını kapsayan 7 . ve 8. sınıf öğrencilerinin bilişsel gelişimlerinin ilerlemesi ile birlikte iletişim becerilerinin de sınıf düzeyi ile birlikte anlamlı bir şekilde arttı̆̆ı görülmektedir.

Ergenin kardeş sayısına göre iletişim becerileri incelendiğinde tek çocuklarla 1 kardeşi olan çocuklar arasında anlamlı bir farklılık görülmezken, 2 ve daha üzerinde kardeşe sahip kardeş sayısı arttıkça iletişim becerileri puanının alt boyutlarında ve toplam puanında düşüş olduğu göze çarpmaktadır. Kerr'in (1991) çalışmasında ise kardeş sayısının iki olması iletişim becerilerine katkı sunarken ikiden fazla olduğu durumlarda ise kardeşler arası çatışma halinin daha fazla olabileceğini belirtmiştir. Özyürek ve Tezel Şahin (2005) tarafından yapılan çalışmada çocuk sayısı arttıkça babanın daha sert-katı olduğu ve demokratik tutumdan uzaklaştığı belirtilmiştir. Anne baba tutumları ile kardeş sayısının karşılaştığı pek çok 
çalışmada benzer şekilde anlamlı farklılık olduğu sonucuna ulaşılmıştır (Aktaş, 2011; Ersoy, 2013; Gürler, 2017; İnci ve Deniz, 2015)

Yapılan araştırma bulguları incelendiğinde, çocuk sayısı arttıkça iletişim becerilerinin düşme nedeninin, iki çocuğa kadar ebeveynlerin nispeten demokratik tutum sergileyebilirken üç çocuktan itibaren çocuk sayısı arttıkça çocukla sağlıklı iletişim kurma ihtimallerinin azalması olduğu düşünülmektedir. Çocukların davranış biçimlerini etkileyen etmenlerin başında ebeveynlerini rol model almaları gelmektedir. Kardeş sayısı arttıkça evdeki sağlıksız iletişimden etkilenen çocukların bu iletişim biçimlerini kendi hayatlarına da uyarladıklarını söylemek mümkün olabilir. Ayrıca çocuk sayısı arttıkça ebeveynlerin çocuklarına ayırdıkları

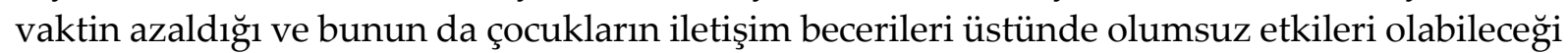
düşünülmektedir. Son olarak çocuk sayısı arttıkça ailenin sosyoekonomik düzeyinin düştüğü görülmektedir buna bağlı olarak hem çocuk sayısının fazla olması hem de sosyoekonomik sebeplerin bir araya gelmesiyle birlikte ev içinde iletişim sıkıntısının yaşanma olasılığının artabileceği de düşünülmektedir yapılmış bazı çalışmaların da bu yönüyle destekler nitelikte olduğunu söylemek mümkündür (Aktaş, 2011; Buhrmester, 1992; Cass 1964; Ersoy, 2013; Gürler, 2017; İnci ve Deniz 2015, Montemayor ve Hanson, 1985).

Çalışmamızda ergenin doğum sırası ile iletişim becerileri arasındaki ilişkinin anlamlı olduğu belirlenmiştir. Bu anlamlı farklılığın doğum sırası yükseldikçe iletişim becerisi puanlarındaki düşüş şeklinde olduğu belirlenmiştir. Eratay (2011) de okul öncesi çocuklarında davranış problemlerini incelediği çalışmasında, çocuğun doğum sırası yükseldikçe problem davranış gösterme durumunun da arttığını saptamıştır. Özyürek (2005) ise çocuk sayısı arttıkça babaların demokratik tutumdan uzaklaşarak daha sert ve katı bir davranış modeli benimsediğinden bahsetmiştir. Bu çalışmalardan yola çıkıldığında doğum sırası yükseldikçe kendisinden önceki kardeşlerde sabrı ve enerjisi azalan ebeveynlerin doğum sırası yüksek olan ergenlerin buhranlı ve karmaşık süreçlerini idare etmede zorlandıkları, daha az toleranslı davranabildiği düşünülmektedir. Toleransı daha düşük ebeveynlere maruz kalan çocukların daha fazla iletişim sıkıntısı yaşadıkları ve buna bağlı olarak akranlarıyla olan iletişimde de benzer sorunları yaşayabilecekleri düşünülebilir.

Ergenin anne-baba öğrenim düzeyine göre iletişim becerisi puanları incelendiğinde sonuçların benzer olduğu göze çarpmıştır. Anne- babaların öğrenim düzeyi lisans olanlarla lisansüstü olanlar arasında anlamlı bir fark görülmezken öğrenim düzeyi düştükçe iletişim becerisi puanlarında da düşüş olduğu göze çarpmaktadır. Taşın (2010) araştırmasında annelerin öğrenim düzeyleri ile çocukların kaygı düzeyleri arasındaki ilişki incelenmiş ve annelerin öğrenim düzeyleri yükseldikçe çocukların kaygı düzeylerinin düştüğünü belirlemiştir. Özbey (2009) tarafından yapılan çalışmada ise okul öncesi eğitim kurumlarda eğitim alan 60-72 aylık çocukların problem davranışları bazı değişkenlere göre incelenmiş ve baba öğrenim düzeyi arttıkça çocukların problem davranış gösterme oranlarının düştügüünü saptanmıştır. Her iki çalışmayı da ele aldığımızda bu çalışmaların temelinde ebeveynlerin çocuklarıyla olan iletişimlerinin niteliği olduğunun söylenmesi mümkündür. Yabancı literatür incelendiğinde benzer şekilde ebeveynlerin öğrenim düzeyleri arttıkça çocuklarının iletişim becerilerinin de arttığıyla ilgili pek çok çalışmaya ulaşılmıştır (Raty, 2006; Reay, 2004; Tudge ve ark., 2006). Ebeveynlerin öğrenim düzeyleri yükseldikçe çocuklarıyla iletişim konusunda daha donanımlı ve gelişime açık oldukları söylenebilir. Araştırmamız da bu yönüyle literatürdeki birçok çalışmayı desteklemektedir. 
Ergenin okul öncesi eğitim alma durumuna ve süresine göre iletişim becerisi puanları incelendiğinde en düşük puan ortalamasının hiç okul öncesi eğitim almayan grupta olduğu görülürken okul öncesi eğitim alma süresi arttıkça iletişim becerisi puanlarında da artış olduğu görülmüştür. Özbey (2009) tarafından yapılan çalışmada okul öncesi eğitim kurumlarında eğitim alan 60-72 aylık çocukların problem davranışları bazı değişkenlere göre incelenmiş ve okul öncesine devam süreleri yükseldikçe çocukların problem davranış gösterme oranlarının düştüğünü saptanmıştır. Pekdoğan (2011), okul öncesi eğitim alan çocuklarla almayan çocukların sözel açıklama ve dinleme becerilerini karşılaştırmış ve okul öncesi eğitim alan çocukların bu becerilerinin daha ilerde olduğu sonucuna ulaşmıştır. Karatekin (2012), okul öncesi eğitim alan çocukların okul öncesi eğitim almayan çocuklara kıyasla iletişim becerilerinde daha yetkin olduğu sonucuna ulaşmıştır. Birçok gelişim alanında olduğu gibi iletişim becerilerinin de temelleri okul öncesi dönemde atılmaktadır. Bu nedenle bu dönemi nitelikli geçiren çocukların ergenlik döneminde iletişim becerilerinin akranlarından daha iyi olacağı söylenebilir (Hancock ve ark., 2002; Qi ve Kaiser, 2004). Bu yönüyle yaptığımız çalışma sonucu literatürdeki benzer çalışmalarla paralellik göstermektedir.

Çalışmaya dâhil edilen ergenlerin cinsiyete göre Problem Çözme Becerilerine ilişkin aldıkları puanlar incelendiğinde;

Araştırmaya dâhil edilen ergenlerin cinsiyete göre problem çözme becerileri puanları incelendiğinde problem çözme alg1sı boyutu ve toplam puanda anlamlı bir farklılık görülmezken problem çözmede isteklilik ve kararlılık alt boyutunda erkeklerin lehine anlamlı farklılık olduğu saptanmıştır. Literatür incelendiğinde problem çözmenin cinsiyet açısından erkekler lehine anlamlı bir farklılık olduğu (Dursun ve Özkan 2020, Gallagher, A.M., ve ark. 1999; Koray ve Azar, 2008; Korku, 2002; Maydeu Olivares, Rodriguez-Fornells, Gomez-Benito ve D'Zurilla, 2000) araştırmalar mevcutken kızların lehine olan araştırmalar da mevcuttur (Pakaslahti ve ark., 2002; Danışık, 2005; Baran, Küçükakça ve Ayran, 2014; Türköz ve Kıralp, 2019). Araştırmamızda erkeklerin iletişim becerileri duygusal boyutunda kızlardan daha yetkin olduğu sonucuna ulaşılmıştı. Bu iki veri 1şığında ergenliğin çalkantılı sürecine kızlardan daha geç giren erkeklerin ergenliğin ilk dönemleri olarak kabul edilen dönemde oldukları varsayılabilir (Gesell, 1957). Bu nedenle henüz ergenliğin duygusal sıkıntılarıyla baş etmek zorunda olmayan erkeklerin duygusal iletişimi bu süreçte daha güçlü olmakta ve problem çözmeye daha istekli ve problem çözmede daha kararlı oldukları söylenebilir.

Araştırmaya dâhil edilen ergenlerin problem çözme becerileri puanlarının öğrenim gördükleri sınıf düzeyi dikkate alınarak incelendiğinde tüm alt boyutlarda ve toplam puanda 7. sınıflara göre 8. sınıflarda öğrenim gören ergenlerin puan ortalamalarında artış olduğu görülmektedir. Benzer şekilde Yılmaz ve arkadaşlarının (2009) yaptığı çalışmada sağlık yüksekokulu öğrencilerinin problem çözme beceri düzeyleri çeşitli değişkenler açısından incelenmiştir. Problem çözme becerisi ile öğrencilerin sınıf düzeyleri arasında anlamlı fark saptanmıştır. İkinci sınıfta öğrenim gören öğrencilerin problem çözme becerilerinin birinci sınıfta öğrenim gören öğrencilere kıyasla daha yüksek olduğu sonucuna ulaşılmıştır. Dünyada yapılmış birçok çalışmada da ergenlerin öğrenim gördükleri sınıf düzeyleri yükseldikçe problem çözme becerilerinin de geliştiği sonucuna ulaşılmıştır (Alumran, 2008; Blanchard ve ark. 1995; Shure, 1983). Ayrıca Mountrose (2000) çalışmasında problem çözme sürecinin beş maddelik aşamadan oluştuğu ve bu aşamalarda ilerlemenin yaşın ilerlemesi ile paralellik gösterdiğini 
belirtmiştir. Literatürdeki çalışmalar yaptığımız araştırmanın bulguları ile paralellik göstermektedir.

Araştırmaya dâhil edilen ergenlerin kardeş sayısına göre problem çözme becerileri incelendiğinde en yüksek puanları tek çocukların ve iki kardeş olan çocukların aldıkları görülürken kardeş sayısı ikinin üzerine çıktığında puanların anlamlı bir şekilde düştüğü saptanmıştır. Adler (2005) çocukların doğum sıralarıyla kişilik yapıları arasındaki ilişkiden bahsederken Gazeloğlu (2000) ikinci çocuktan sonraki çocukların daha diştan denetimci olduklarının altını çizmiştir. Düzakın (2004) tarafından yapılan araştırmada, lise öğrencilerinin problem çözme becerileri bazı değişkenler (anne baba tutumları, okul türü, sınıf düzeyi, öğrencinin kardeşler arasında sahip olduğu doğum sırası, kardeş sayısı, cinsiyet) açısından incelenmiştir. Tek çocuklarla bir kardeşi olan yani iki kardeş olan çocuklar arasında problem çözme becerisi arasında bir fark olmadığı belirtilirken üç kardeşten itibaren kardeş sayısı arttıkça problem çözme becerisinde düşüş olduğu belirtilmiştir. Kaytez ve Kadan (2016) ise tek çocukların ve kendisi dahil iki kardeş olan çocukların problem çözme becerilerinin daha yüksek olduğu sonucuna ulaşmıştır. Araştırmamızda da benzer bulgular ortaya çıkmıştır. Bu bulgular yorumlanırken kardeş sayısına ek olarak anne - baba öğrenim düzeyiyle de açılanabileceği düşünülmektedir. Çünkü anne baba öğrenim düzeyi ile çocuk sayısı arasındaki ilişki incelendiğinde ebeveynlerin öğrenim düzeyleri yükseldikçe çocuk sayısında düşüş olduğu da göze çarpmaktadır.

Araştırmaya dâhil edilen ergenlerin doğum sırasına göre problem çözme becerileri incelendiğinde en yüksek puanları ilk çocukların aldıkları görülürken, doğum sırası yükseldikçe puanların anlamlı bir şekilde düştügü saptanmıştır. Leman (1997), ilk çocukların daha fazla kendine güvenen ve yüksek konsantrasyon gücü olduğundan bahsetmiştir (Akt: Düzakın, 2004). İlk çocukların kardeşlerin problemleriyle de zaman zaman ilgilendikleri ve bu nedenle problem çözme becerilerinin çok küçük yaşlardan itibaren yoğun bir şekilde kullanıldığının söylenmesi mümkündür. Sulloway (1996)'e göre kardeşler arasındaki çatışmanın nedeni sınırlı olan ebeveyn kaynaklarının paylaşımıdır. Bu paylaşım sürecinde ise eve gelen ilk çocukların diğerlerine göre daha avantajlı olduğudur. Torun ve arkadaşları (2012) çalışmalarında, doğum sırası ilerledikçe ebeveynlerin çocuklarına ayırdıkları zamanın kalitesinin azaldığını, çocuk duygu, istek ve düşüncelerini daha zor ifade ettiğini belirtmiştir. Doğum sırası ile problem çözme becerisi arasındaki ilişkinin ebeveyn çocuk iletişiminden kaynaklanabileceği düşünülmektedir.

Araştırmaya dâhil edilen ergenlerin anne baba öğrenim düzeyine göre problem çözme becerileri incelendiğinde ebeveynlerin öğrenim düzeyleri arttıkça ergenlerin problem çözme becerileri puanlarının da yükseldiği görülmüştür. Literatürdeki diğer çalışmalar incelendiğinde, anne ve babaların öğrenim düzeyi arttıkça çocuklarına karşı demokratik tutumlarının arttığını, öğrenim düzeyi düştükçe ebeveynlerin daha otoriter bir tutum sergiledikleri sonucuna ulaşılmıştır (Özyürek, 2005; Mızrakçı, 1994; Şendoğdu, 2000; Yalkın, 1994; Yavuzer, 2009; Zincirkıran, 2008). Ebeveynlerin demokratik tutumla çocukları ile iletişim kurduklarında ve çocukların mevcut problemlerini farklı yol ve yöntemlerle çözme denemelerine daha ılımlı yaklaşabilmektedir. Erken yaşlardan itibaren farklı şekillerde problemlerini çözmeye çalışan çocuklarına destek olan ebeveynlerin çocuklarının problem çözme becerileri gelişmektedir. Ebeveynlerin öğrenim düzeyleri arttıkça ergenlerin problem çözme becerilerinin de arttığıyla ilgili literatürde de benzer sonuçlara ulaşılan çalışmalar 
bulunmaktadır bu nedenle yaptığımız çalışmanın literatürdeki diğer çalışmaları destekler nitelikte olduğu düşünülmektedir.

Ergenin okul öncesi eğitim alma durumuna ve süresine göre ergenin problem çözme becerisi puanları incelendiğinde en düşük puan ortalamasının hiç okul öncesi eğitim almayan grupta olduğu görülürken okul öncesi eğitim alma süresi arttıkça problem çözme becerisi puanlarında da artış olduğu görülmüştür. Okul öncesi eğitim programının temel amaçlarından biri problem çözme becerisinin kazandırılmasıdır (Dinçer, A. 2005). Okul öncesi eğitim çocukların gelişimini desteklemenin yanında birçok becerinin kazanılmasına da zemin hazırlamaktadır (Finnish National Agency for Education, 2017). Yaşamının ilk döneminden itibaren problem çözme becerileri desteklenen bireylerin hayatlarının devamında da akranlarına kıyasla problem çözme becerilerinde daha yetkin olduklarının söylenmesi mümkündür. Dinçer (2005)'in çalışmasında yer verdiği ifade yaptığımız çalışma sonuçlarını destekler niteliktedir.

“İlköğretim Öğrencileri İçin Problem Çözme Becerilerine Yönelik Alg1 Ölçeği” ve "İletişim Becerileri Envanteri" alt boyutları ve toplam puanları arasındaki ilişki değerlendirildiğinde anlamlı olduğu göze çarpmaktadır. Uzuntaş (2013), problem çözme becerisi ile iletişim becerilerinin iç içe geçmiş ve birbirlerini etkileyen beceriler olduğunu belirtmiştir. Çünkü kendini iyi ifade edebilen bireylerin diğer bireyleri de iyi anladığı ve çatışmaları iyi yönetebildiğini bununla beraber problemleri daha rahat çözüme kavuşturabildiklerinin altını çizmiştir.

$\mathrm{Bu}$ araştırma;

1. 2019-2020 eğitim-öğretim yılında Bolu ilinde MEB'e bağlı devlet ortaokulunda öğrenim gören öğrencilerle sinırlıdır.

2. “İlköğretim Öğrencileri İçin Problem Çözme Becerilerine Yönelik Alg1 Ölçeği" ve "İletişim Becerileri Envanteri” nden elde edilen verilerle sınırlıdır.

Bu sonuçlar doğrultusunda aşağıdaki öneriler sunulmuştur:

Alan çalışanları;

- Ergenliğin ilk döneminin çalkantılarıyla mücadele eden 7. ve 8. sinıf öğrencilerine ve ailelere, ergenlik döneminin genel özellikleri, bu süreçte yaşanabilecek sıkıntılar ve bu sıkıntılarla baş etmeleri için kullanabilecekleri yollar hakkında bilgilendirme yapılabilir.

- Ergenlerin yaşları itibari ile yaşadıkları Problemleri konuşabilecekleri Sosyal Hizmet birimleri okullarda daha işlevsel olabilir.

- Kızların ergenlik sürecinin daha erken başladığı göz önünde bulundurularak ergenlik dönemiyle ilgili kızlara özel eğitim programları ayrıca hazırlanabilir.

- Okul öncesi eğitim alan çocukların ergenlik döneminde hem problem çözme hem de iletişim becerilerinde akranlarından daha iyi olduğu yapılan analizler sonucunda görüldüğünden dolayı okul öncesi dönemden itibaren her dönemin özelliklerine göre uygun problem çözme ve iletişim becerileri eğitim programları oluşturulmalıdır. Çeşitli aile katılım çalışmaları aracılığıyla ebeveynlerle iş birliği geliştirebilir. Ebeveynler ile ergenlerin daha etkili iletişim kurmaları sağlanabilir.

- Çalışma sonuçlarında çocuk sayısı ikiden fazla olan ailelerdeki ergenlerin hem problem çözme hem de iletişim becerilerinde akranlarının gerisinde kaldıkları saptanmıştır. 
$\mathrm{Bu}$ nedenle, çocuk sayısı ikiden fazla olan aileler takip edilebilir ve eğitsel destekler sağlanabilir.

- Son dönemde internetin ve dolayısıyla sosyal medyanın ergenlerin hayatlarına dahil olmasıyla birlikte ergenler sanal ortamlarda farklı şekillerde iletişim sıkıntılarıyla ve problemleri ile mücadele etmektedir. Bu nedenle internet ortamında 18 yaş altı bireylerin denetimi ve korunmasıyla ilgili önlemler geliştirilebilir.

Araştırmacilar;

- Hem ergenlerin hem de ebeveynlerinin iletişim becerileri değerlendirilerek ergenler ile ebeveynleri arasındaki iletişim becerilerinin ilişkisi incelenebilir.

- Hem ergenlerin hem de ebeveynlerin problem çözme becerileri değerlendirilerek ergenler ile ebeveynleri arasındaki problem çözme becerilerinin ilişkisi incelenebilir.

- İletişim ve problem çözme becerilerinin toplum içinde zamana bağlı olarak değişimlere uğramasından dolayı toplumun ihtiyaçları göz önüne alınarak orta okul programına uygun, iletişim ve problem çözme becerileri eğitim programları geliştirilebilir.

- Teknolojinin sosyal hayatın içine yoğun olarak girdiği son yıllarda internet ve dolayısıyla sosyal medya insan hayatına daha çok dahil olmuştur. Bu nedenle iletişimin de bir bölümünün bu mecralarda ilerlediği dikkati çekmektedir. İnternetin iletişim amaçlı kullanımındaki artış göz önünde bulundurularak ergenlerin internet ortamlardaki iletişim biçimleriyle ilgili ve problem yaşamaları durumunda yapılabilecekler konusunda okul, aile ve ergenin iş birliği içinde olabileceği eğitimler planlanabilir.

\section{KAYNAKÇA}

Abalı, O. (2004). Problems of adolescence. (8. Baskı). İstanbul: Kelebek Publication.

Adler, A. (2005). Çocuk eğitimi. (Çev.Kamuran Şipal). (3. Baskı). İstanbul: Cem Yayınevi.

Akçam, A. (2019). Ortaokul öğrencilerinin iletişim becerileri ve Türkçe dersine yönelik tutumlarının çeşitli değişkenler açısından incelenmesi. Yayımlanmamış yüksek lisans tezi, Kırşehir Ahi Evran Üniversitesi, Sosyal Bilimler Enstitüsü, Kırşehir.

Akçinar, B., Baydar, N. ve Kağıtçıbaşı, Ç. (2018). Erken Ergenlikte ahlak gelişimi: Bir müdahale araştırması. Eğitimde Kuram ve Uygulama, 14(2), 153-169.

Akdeniz, S. (2017). Erken ergenlikte bilişsel duygu düzenleme, algilanan anne baba tutumu ve algilanan sosyal destek ile psikolojik sağlik arasindaki ilişkinin incelenmesi. Yayımlanmamış yüksek lisans tezi, Yildirim Beyazit Üniversitesi, Sosyal Bilimler Enstitüsü, Ankara.

Aksüt, M. ve Batur, Z. (2007). Internet perspektifinde sosyalleşme ve iletişim kurma süreci.

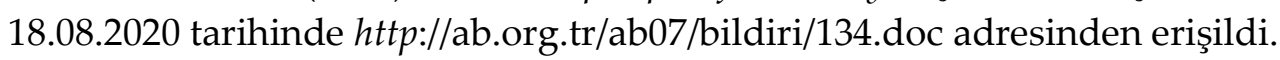


Akkaya, M. A. (2018). Önce insan, önce iletişim: Bilgi ve belge yöneticileri için halkla ilişkiler. Türk Kütüphaneciliği, 32(1), 59-61.

Aktaş, S. (2011). 9. sınıfta anne baba tutumları ve benlik saygısı arasındaki ilişkinin bazı değişkenler açısından incelenmesi. Yayınlanmamış yüksek lisans tezi, Selçuk Üniversitesi, Eğitim Bilimleri Enstitüsü, Konya.

Alumran, J. ve Punamäki, R. (2008). Relationship between gender, age, academic achievement, emotional intelligence, and coping styles in bahraini adolescents. Individual Differences Research, 6(2), 104-119.

Andersen, S. L. (2003). Trajectories of brain development: point of vulnerability orwindow of opportunity. Neurosci Biobehav Review, 27, 3-18.

Arthur, R. (1975). An Approach to teaching parents and adolescents problem-solving communication skills. The Annual Meeting of the Eastern Psychological Association, 26.

Aydın, B. (2005). Çocuk ve ergen psikolojisi. Ankara: Atlas Yayıncılık.

Aydın, İ. (2015). Ders dışı sportif etkinliklere katılan ve katılmayan öğrencilerin duygusal özerkliklerinin incelenmesi. Yayımlanmamış yüksek lisans tezi, Karadeniz Teknik Üniversitesi Eğtitim Bilimleri Üniversitesi, Trabzon.

Baran, M., Küçükakça, G., ve Ayran, G. (2014). Sağlık yüksekokulu öğrencilerinde algılanan sosyal destek düzeyinin sigara kullanımı üzerine etkisi. ADÜ Tıp Fakültesi Dergisi, 15(1), 9-15.

Bayraktar, F. (2007). Olumlu ergen gelişiminde ebeveyn/akran ilişkilerinin önemi. Çocuk ve Gençlik Ruh Sağlı̆̆ı Dergisi, 14(3), 157-166.

Blanchard-Fields, F., Jahnke, H. C., \& Camp, C. (1995). Age differences in problem-solving style: the role of emotional salience. Psychology and Aging, 10(2), 173-180.

Büyüköztürk, Ş., Çakmak, E. , Akgün, Ö., Karadeniz, Ş. , Demirel, F. (2008). Bilimsel araştırma yöntemleri. (1. Bask1). Ankara: Pegem Akademi.

Cenkseven, F. ve Akar, F. (2006). Ergenlerin düşünme gereksinimi ve cinsiyetlerine göre problem çözme becerilerinin karşılaştırılması. Eurasian Journal of Educational Research, $25,45-53$.

Dahl, R.E. (2004). Adolescent brain development: a period of vulnerabilities and opportunities. Annals of the New York Academy of Sciences, 1021, 1-22.

Danışık, N. D. (2005) Ergenlerin sürekli öfke ifade tarzları ile problem çözme becerileri arasındaki ilişki. Yayınlanmamış yüksek lisans tezi, Abant İzzet Baysal Üniversitesi, Sosyal Bilimler Enstitüsü, Bolu.

Dinçer, Ç. (2005). Okul öncesi dönemde kişiler arası bilişsel problem çözme becerilerinin geliştirilmesi. Eurasian Journal of Educational Research, 20, 122-134.

Dursun, A. ve Özkan M.S. (2020). Ergenlerin yaşadıkları yer ve cinsiyet açısından sosyal destek ile problem çözme becerileri. Türkiye Bütüncül Psikoterapi Dergisi, 3(6), 18-32. 
Düzakın, S. (2004). Lise öğrencilerinin problem çözme becerilerinin bazı değişkenler açısından incelenmesi. Yayınlanmamış yüksek lisans tezi, Gazi Üniversitesi, Eğitim Bilimleri Enstitüsü, Psikolojik Danışma ve Rehberlik Bilim Dalı, Ankara.

Ekşi, F. (2013). Bir kişilerarası iletişim problemi olarak internet bağımlılığı ve siber zorbalık: psikolojik danışma açısından değerlendirilmesi. Değerler Ĕ̆gitimi Dergisi, 11(25), 91-11.

Ekici İnel, D. ve Balım, A. (2013). Ortaokul öğrencileri için problem çözme becerilerine yönelik algı ölçeği: Geçerlilik ve güvenirlik çalışması. Yüzüncü Yıl Üniversitesi Eğitim Fakültesi Dergisi, 10(1), 67-86.

Eldeleklioğlu, J. (2008). Ergenlerin zaman yönetimi becerilerinin kaygı, yaş ve cinsiyet değişkenleri açısından incelenmesi. İlköğretim Online, 7(3), 656-663.

Eratay, E. (2011). Okul öncesi çocuklarında davranış problemleri. Journal Of New World Sciences Academy, 6(3), 2347-2362.

Erikson, E. (1982). Insanın 8 evresi. (Çev. Gonca Akkaya). İstanbul: Okyanus Yayınevi.

Erözkan, A. (2009). Lise öğrencilerinde kişilerarası ilişki tarzlarının yordayıcıları. Selçuk Üniversitesi Sosyal Bilimler Enstitüsü Dergisi, 21, 543-551.

Ersanlı, K. ve Balcı, S. (1998). İletişim becerileri envanterinin geliştirilmesi: Geçerlik ve güvenirlik çalışması. Türk Psikolojik Danışma ve Rehberlik Dergisi, 10, 7-12.

Ersoy, E. (2013). Ortaokul öğrencilerinin algıladıkları anne baba tutumları ile benlik saygısı ve depresyon düzeyi arasındaki ilişkinin incelenmesi. Yayınlanmamış yüksek lisans tezi. Fatih Üniversitesi, Sosyal Bilimler Enstitüsü, İstanbul.

Fetihi, L. (2002). Ergenlik ve toplum. Eğitim ve Bilim Dergisi, 27(125), 62-68.

Finnish national agency for education. (2017). Finnish education in a nutshell. 10 Şubat 2020 tarihinde

http://www.oph.fi/download/146428 Finnish Education in a Nutshell.pdf. adresinden erişildi.

Gallagher, A.M., Delisi, R.; Holst, P. C; Mcgillicuddy-Delisi, V.; Morely, M.; Cahala, C. (1999). Gender differences in advanced mathematical problem solving. Journal of Experimental Child Psychology, 75(3), 165-244.

Gardner, H. (2019). Eğitilmemiş zihin. (Çev. Merve Özenç Kasımoğlu). İstanbul: Alfa Bilim Yayınevi.

Gazeloğlu, C. (2000). İlkokul 4. sını öğrencilerinin psiko-sosyal gelişimine ana-baba tutumunun etkisinin incelenmesi. Yayımlanmamış yüksek lisans tezi, Hacettepe Üniversitesi, Sağlık Bilimleri Enstitüsü, Ankara.

Geldard, K. ve Geldard, D. (2013) Ergenler ve gençlerde psiklojik danışma. (4. Baskı). (Çev. Metin Pişkin). Ankara: Nobel Yayınları.

George, D. ve Mallery, P. (2010). SPSS for windows step by step: A simple guide and reference 17.0 update. (10. Bask1). Boston: Pearson.

Gesell, A. (1957). Youth; the years from ten to sixteen. Newyork: Harper and Brothers. 
Gülay Ogelman, H. ve Erten Sarıkaya, H. (2013). Okul öncesi eğitimi almış çocukların akran ilişkileri değişkenlerinin 5 ve 6 yaşta incelenmesi: İki yıllık boylamsal çalışma. Turkish Studies - International Periodical for the Languages, Literature and History of Turkish or Turkic, 8(8), 1859-1871.

Gürhan, N., Meriç, M., Kaya, B., Turan, N. D. ve Kabataş, E. (2018). Tıp fakültesi ve hemşirelik öğrencilerinde intihar olasılığı ve problem çözme becerilerinin sosyodemografik değişkenler açısından karşılaştırılması. Gümüşhane Üniversitesi Sağlık Bilimleri Dergisi, 7(1), 149-155.

Gürler, A. (2017). Ergenlerde anne baba tutumlari ile benlik saygisi arasindaki ilişkinin incelenmesi: Başakşehir örneği. Yayımlanmamış yüksek lisans tezi, İstanbul Ticaret Üniversitesi, Sosyal Bilimler Enstitüsü. İstanbul.

Hancock, T., Kaiser, A., ve Delaney, E. (2002). Teaching parents of preschoolers at high-risk: Strategies to support language and positive behavior. Topics in Early Childhood Special Education, 22, 191-212.

Helen, G. (1994). Developing problem solving and interpersonal communication skills through intentionally structured groups. Journal for Specialists in Group Work, 19, 4347 .

İnci, M. A. ve Deniz, Ü. (2015). Baba tutumları ile çocuğun yaşı, cinsiyeti, doğum sırası ve kardeş sayısı değişkenleri arasındaki ilişkinin incelenmesi. Karadeniz Sosyal Bilimler Dergisi, 57, 1-9.

Karatekin, K., Sönmez, Ö.F. ve Kuş, Z. (2012). İlköğretim öğrencilerinin iletişim becerilerinin çeşitli değişkenler açısından incelenmesi. Electronic Turkish Studies, 7(3), 1695-1708.

Kaytez, N. ve Kadan, G. (2016). Okul öncesi dönem çocuklarında akademik benlik saygısı ile kişiler arası problem çözme becerilerinin incelenmesi. Ĕ̆gitim ve Öğretim Araştırmaları Dergisi, 5(38), 332-342.

Kerr, M. (1991) Background factors predicting teacher ratings of children performance. Social Study of Behavioral Development, 5(2), 17-25.

Kılıç, M. (2013). Gerçek yaşam tadında, gelişim dönemleri. Ankara: Pegem Akademi.

Kocayörük, E. (2010). Ergen gelişiminde aile işlevleri ve baba katılımı. Türk Psikolojik Danışma ve Rehberlik Dergisi, 4(33), 37-45.

Koçyiğit, M., Koçyiğit, A. ve Özsoy, E. (2018). Kişilerarası iletişim bağlamında bireylerin iletişim becerileri ile stresle başa çıkma düzeyleri arasındaki ilişkinin incelenmesi: Milli sporcular üzerinde bir araştırma. Türk Spor Bilimleri Dergisi, 1(1), 11-19.

Koray, Ö. ve Azar, A. (2008). Ortaöğretim öğrencilerinin problem çözme ve mantıksal düşünme becerilerinin cinsiyet ve seçilen alan açısından incelenmesi. Kastamonu Ĕ̆itim Dergisi, 10(2), 290-305.

Korkut, F. (2002). Lise öğrencilerinin problem çözme becerileri. Hacettepe Üniversitesi, Eğitim Fakültesi Dergisi, 22, 177-184.

Kumru, A., Carlo, G. Ve Edwards, C. P. (2004). Olumlu sosyal davranışların ilişkisel, kültürel, bilişsel ve duyuşsal bazı değişkenlerle ilişkisi. Türk Psikoloji Dergisi, 19(54), 109-128. 
Martin, M., Anderson, C., Burant, P. ve Weber, B. (1997). Verbal aggression in sibling relationships. Communication Quarterly, 45(3), 304-317.

Maydeu-Olivares, A., Rodríguez-Fornells, A., Gómez-Benito , J. ve D'Zurilla, T.J. (2000). Psychometric properties of the spanish adaptation of the social problem-solving inventory-revised (SPSI-R). Personality and Individual Differences, 29, 699-708.

McMaster, L. E., Connolly, J., Pepler, D., ve Craig, W. M. (2002). Peer to peer sexual harassment in early adolescence: a developmental perspective. Development and Psychopathology, 14(1), 91-105.

Mizrakçı, Ş. (1994). Annelerin çocuk yetiştirme tutumlarına etki eden faktörler: demografik özellikleri, kendi yetiştiriliş tarzları, çocuk gelişimine ilişkin bilgi düzeyleri ve çocuğun mizacına ilişkin algıları. Yayımlanmamış yüksek lisans tezi, Sosyal Bilimler Enstitüsü, Ege Üniversitesi, İzmir.

Milli, M. S. ve Yağcı, U. (2017).Öğretmen adaylarının iletişim becerilerinin incelenmesi. Abant İzzet Baysal Üniversitesi Eğitim Fakültesi Dergisi,17(1), 286-298.

Monique, L.; Shannon, S.; Desti, S. ve Mary Lou, K. (2011). Buffering the effects of violence: communication and problem-solving skills as protective factors for adolescents exposed to violence. Journal of Community Psychology, 39(3), 353-367.

Montemayor, R., ve Hanson, E. (1985). A naturalistic view of conflict between adolescents and their parents and siblings. Journal of Early Adolescence, 5, 23-30.

Mountrose, P. (2000). Eğ̀itim. 6 ile 18 yaş çocuklarıla sorunları çözmede 5 aşama. İstanbul: Kariyer Yayıncilık.

Nock, M. K. ve Mendes, W. B. (2008). Physiological arousal, distress tolerance, and social problem solving deficits among adolescent self-injurers. Journal of Consulting and Clinical Psychology, 76, 28-38.

Özbey, S., ve Alisinanoğlu, F. (2009). Okul öncesi eğitim kurumuna devam eden 60- 72 aylık çocukların problem davranışlarının bazı değişkenlere göre incelenmesi. Uluslar Arası Sosyal Araştırmalar Dergisi, 2(6), 493-517.

Özyürek, A. ve Tezel Şahin, F. (2005). 5-6 yaş grubunda çocuğu olan ebeveynlerin tutumlarının incelenmesi. Gazi Ĕ̆itim Fakültesi Dergisi, 25(2),19-34.

Pakaslahti, L., Karjalainen, A., ve Keltikangas-Järvinen, L. (2002). Relationships between adolescent prosocial problem-solving strategies, prosocial behaviour, and social acceptance. International Journal of Behavioral Development, 26(2), 137-144.

Pekdoğan, S. (2011). Okul öncesi eğitim kurumuna devam eden beş altı yaş çocuklardaki sosyal becerilerin bazı özellikler açısından incelenmesi (Elazı̆̆ İli Örneği). Yayımlanmamış yüksek lisans tezi, İnönü Üniversitesi, Eğitim Bilimleri Enstitüsü, Malatya.

Pelit, E., Karaçor, M. ve Kılıç, İ. (2018). Duygusal zekânın iletişim becerilerine etkisi: Turizm öğrencileri üzerinde bir araştırma. Dokuz Eylül Üniversitesi Sosyal Bilimler Enstitüsü Dergisi, 20(1), 85-107.

Piji Küçük, D. (2012). Müzik öğretmenliği anabilim dalı öğrencilerinin iletişim ve problem çözme becerileri. Gazi Üniversitesi Gazi Eğitim Fakültesi Dergisi, 32(1), 33-54. 
Qi, C. H., ve Kaiser, A. P. (2004). Problem behaviors of low-income children with language delays: An observation study. Journal of Speech. Language, and Hearing Research, 47(3), 595-609.

Raty, H. (2006). What comes after compulsory education? A follow-up study on parental expectations of their child's future education. Educational Studies, 32(1), 1-16.

Reay, D. (2004). Education and cultural capital: The implications of changing trends in education policies. Cultural Trends, 13(2), 73-86.

Sadowski, Kelley, C. ve Lou, M. (1993). Social problem solving in suicidal adolescents. Journal of Consulting and Clinical Psychology, 61(1), 121-127.

Say, G. (2016). Problemli internet kullanımı ile ilişkili bazı değişkenler: Ebeveyn-ergen ilişki niteliği, yalnızlı, öfke ve problem çözme becerileri. Yayımlanmamış yüksek lisans tezi, Ankara Üniversitesi, Sosyal Bilimler Enstitüsü, Ankara.

Serin, N. ve Derin, R. (2008). İlköğretim öğrencilerinin kişilerarası problem çözme becerisi algıları ve denetim odağı düzeylerini etkileyen faktörler. Uluslararası İnsan Bilimleri Dergisi, 8(1), 1-18.

Shure, M. B. (1985). ICPS and beyond: Centripetal and centrifugal forces. American Journal of Community Psychology, 13(3), 226-243.

Sulloway, Frank J. (1996). Born to rebel. New York: Pantheon Books.

Spear, L.P. (2000). The adolescent brain and age-related behavioral manifestations. Neurosci Biobehav Review, 24(4), 417-463.

Stemberg, L. (2007). Ergenlik. (Çev. Figen Çok). Ankara: İmge Kitapevi.

Sungur, S. A. (2018). Üniversite öğrencilerinin iletişim becerileri algısı ile kişilerarası ilişki boyutları arasındaki ilişkinin değerlendirilmesi. Selçuk Üniversitesi İletişim Fakültesi Akademik Dergisi, 11(2), 126-138.

Suzanne, R., Ariel, F. ve Mackenzie, F. (2020). Look who's talking: a survey of pediatric program directors on communication skills education in pediatric residency programs. Academic Pediatrics, 20(1), 9-13.

Şendoğdu, M. C. (2000). Anaokuluna devam eden 5-6 yaş çocuklarının anne babalarımı algılamaları ile anne babaların kendi tutumlarını algılamaları arasındaki ilişki. Yayımlanmamış yüksek lisans tezi, Gazi Üniversitesi, Sosyal Bilimler Enstitüsü, Ankara.

Taşın, S. (2010). 5-6 Yaş Grubu çocuklarda karşılaşılan davranış problemlerinin ve annelerinin çocuk yetiştirme tutumlarının incelenmesi. Yayınlanmamış yüksek lisans tezi, Abant İzzet Baysal Üniversitesi, Sosyal Bilimler Enstitüsü, Bolu.

Taylor, L.; Leary, K.; Boyle, A.; Bigelow, K.; Henry, T. ve Derosier, M. (2015). Parent training and adolescent social functioning: a brief report. Journal of Child \& Family, 24(10), 30303037.

Tekiner, Ö. (1997). Okulöncesi eğitiminde yeni yaklaşımlar. Okulöncesi Ĕ̆itim Sempozyumu, 3031. 
Tepeköylü-Öztürk, Ö. ve Soytürk, M. (2015). Beden eğitimi, müzik ve resim/görsel sanatlar öğretmenlerinin iletişim becerilerinin incelenmesi. Ahi Evran Üniversitesi Kırşehir Eğitim Fakültesi Dergisi, 16(3), 39-50.

Torun, S.; Sevban A.; Evsen N.; Akbaş M. ve Yalçın, S. (2012). Hemşirelik öğrencilerinin benlik saygısı ve boyun eğici davranışlarının incelenmesi. Cumhuriyet Tıp Dergisi, 34, 399404 .

Tudge, J., Odero, D., Piccinini, C., Doucet, F., Sperb, T. M. ve Lopes, R.S. (2006). A window into different cultural worlds: young children's everyday activities in the United States, Brazil, and Kenya. Child Development 77(3), 1446-1469.

Turgut, M., Kutlu, G. ve Mut, S. (2018). Sağlık yönetimi bölümü öğrencilerinin iletişim becerileri ile sosyal medya kullanımları arasındaki ilişkinin belirlenmesi. İşletme Bilimi Dergisi, 6(1), 185-205.

Türköz, S. ve Kıralp, F. S. (2019). Öğretmen adaylarının öznel iyi oluş, algılanan sosyal destek ve kendini saklama düzeylerinin incelenmesi. OMÜ Ĕ̆itim Fakültesi Dergisi, 38(2), 5166.

Uzuntaş, A. (2013). Etkili iletişim: anlatabilmek ve anlayabilmek. Kastamonu Eğitim Dergisi, 21(1), 11-30.

Yalkın, S. (1994). Parental expectancies of developmental time-tables, child-rearing attitudes and actual child development. Yayımlanmamış yüksek lisans tezi, Sosyal Bilimler Enstitüsü, Boğaziçi Üniversitesi, İstanbul.

Yavuzer, H. (2009). Ana - baba ve çocuk. İstanbul: Remzi Kitabevi.

Yılmaz, E., Karaca, F. ve Yılmaz, E. (2009). Sağlık yüksekokulu öğrencilerinin problem çözme becerilerinin bazı değişkenler açısından incelenmesi. Atatürk Üniversitesi Hemşirelik Yüksekokulu Dergisi, 12(1), 38-48.

Y1lmaz, N. (2011). Okul öncesi öğretmenlerinin iletişim becerileri, problem çözme becerileri ve empatik eğilim düzeyleri. Yayımlanmamış yüksek lisans tezi, Eğitim Bilimleri Enstitüsü, Muğla Sitkı Kocaman Üniversitesi, Muğla.

Yorulmaz, M. ve Kiraç, R. (2019). Duygusal zekâ ile iletişim becerisi arasindaki ilişkinin incelenmesi. International Health Sciences and Management Conference, İstanbul, 128131, İstanbul.

Williams, J. ve Reid, R. (2010). Developing problem solving and communication skills through memo assignments in a management science course. Journal of Education for Business, 85(6), 323-329.

World Economic Forum (2018). The future of jobs report. Switzerland.

Zincirkıran, Z. (2008). Okul öncesi eğitim kurumlarına devam eden 6 yaş grubu çocukların benlik kavramlarının bazı değişkenlere göre incelenmesi. Yayınlanmamış yüksek lisans tezi, Maltepe Üniversitesi, Sosyal Bilimler Enstitüsü, İstanbul. 